\title{
GENOMIC DIFFERENCES DETECTED IN THE OIL PALM TRUNCATED LEAF SYNDROME (TLS) RAMETS (Elaeis guineensis Jacq.) USING THE REPRESENTATIONAL DIFFERENCE ANALYSIS (RDA) APPROACH
}

\author{
SILVARAJOO, $K^{\star}$; NAMASIVAYAM, $\mathrm{P}^{\star} ; \mathrm{HO}, \mathrm{C} \mathrm{L}^{* *}$ and ALWEE, S S R S
}

\begin{abstract}
Truncated Leaf Syndrome (TLS) is a commonly found abnormality amongst tissue cultured plantlets of oil palm (Elaeis guineensis Jacq.) which, if severe, will eventually lead to the death of the ramets. It was hypothesised that this phenotype could be due to genetic variability. As such, Genomic Representational Difference Analysis (G-RDA) was carried out to identify potential markers that can be used in tissue culture process for early determination of TLS ramets. A total of 18 unique sequences were successfully obtained. Primers were designed and verification of G-RDA products through polymerase chain reaction (PCR) analyses and sequence comparison was carried out using 12 clones of TLS and normal oil palm ramets. Two out of 18 set of primers [F4(6)-1181Bgl and F4(10)-1181Bgl] were identified as potential markers and further verified by PCR and Southern analyses. The primer set F4(6)-1181Bgl was only able to distinguish between TLS and normal ramet of only one genotype (Yangambi) with the presence of expected band in TLS but was absent in normal ramet. The primer set F4(10)-1181Bgl showed the presence of multiple banding pattern in the genotype of La Me and Yangambi. Analysis of the multiple band sequences revealed that those sequences represent multiple regions within the same genome, they are potentially polymorphic markers. The two primer sets mentioned above could be classified as potential genotype specific primers as it is only functional in selected genotype. Further verification with extensive number of samples is needed to elucidate the potential of the above two primer sets to be used as markers across all genotypes of oil palm.
\end{abstract}

Keywords: somaclonal variant, tissue culture abnormality, clonal palm, DNA marker.

Date received: 22 June 2017; Sent for revision: 21 July 2017; Received in final form: 25 October 2017; Accepted: 10 January 2018.

Department of Cell and Molecular Biology,

Faculty of Biotechnology and Biomolecular Sciences,

Universiti Putra Malaysia, 43400 UPM Serdang,

Selangor, Malaysia.

E-mail: parameswari@upm.edu.my

** Institute of Tropical Agriculture, Faculty of Biotechnology and Biomolecular Sciences, Universiti Putra Malaysia, 43400 UPM Serdang, Selangor, Malaysia.

* FELDA Biotechnology Centre, PT 23417, Lengkuk Technology, Persiaran Technology, Techpark@Enstek, 71760 Bandar Enstek, Negeri Sembilan, Malaysia.

\section{INTRODUCTION}

Oil palm has become the most important commodity crop in Malaysia with the increase production of palm oil from 4.1 million tonnes in 1985 to 19.2 million tonnes and its exports reached 18.1 million tonnes in 2013 (MPOB, 2014). The increasing demand for palm oil with desired characteristics is very important and this is not achievable using conventional breeding method that has a generation 
period of 20 years (Abdullah et al., 2005). Thus, the biotechnological method such as tissue culture is the most reliable method to generate oil palm ramets (Corley and Tinker, 2003). The propagation of oil palm through tissue culture was started as early as 1960s (Corley and Tinker, 2003). In 1970s, Jones (1974) is among the first to describe the propagation of the oil palm by tissue culture method. There are several advantages shown in tissue culture of oil palm compared to the conventional breeding method, where the offspring produced via tissue culture is identical to that of original planting material and has the ability of producing new novel planting materials (Sogeke, 1998). Soh et al. (2001) presented that improvement in oil yield between $20 \%-30 \%$ is achievable using tissue culture process compared to the conventional method. However, the tissue culture process of oil palm sometimes generates somaclonal variants or abnormal palms (Corley et al., 1986).

The term somaclonal variation is best described as genetic variation that is observed in plantlets regenerated from tissue culture process (Matthes et al., 2001; Oh et al., 2007). Truncated Leaf Syndrome (TLS) is one of the somaclonal variations found in oil palm clonal ramets and was first reported by Tan et al., in 1999. The TLS is a type of vegetative abnormality which is only obvious when the tissue cultured oil palm plantlets are transferred from culture media to the nursery. In TLS ramets, stunted growth with lesser number of roots and the leaves looking like grasshopper damage are the major visible differences compared to the normal ramets, which will eventually lead to the death of the ramets, if severe. Recent phenotypic and morpho-histological analysis on TLS ramets (Habib et al., 2012a) reported that this plant is less vigorous compared to wild type ramets with such a characteristic of reduced height, lesser green leaves, lesser number of roots, smaller shoot apical meristem and drastically deformed stomata. Initially, Tan and colleagues (1999) suggested that the occurrence of TLS could be due to environmental factor and boron deficiency. More recently, Habib et al. (2012b) reported that deficiency in boron alone may not be the main cause of the TLS but also attributed by zinc deficiency too. In addition, the excessive synthesis and accumulation of cytokinins and brassinosteroids in TLS ramets, could also influence boron and zinc uptake in TLS ramets (Habib et al., 2012b).

However, to date there is no detailed report on the genetic differences between the TLS and wild type oil palm ramets. A number of molecular techniques are currently available to detect the genetic differences between the two genomes, such as Random Amplified Polymorphic DNA (RAPD) (Welsh and McClelland, 1990), Amplified Fragment Length Polymorphisms (AFLP) (Vos et al., 1995) and Genomic Representational Difference Analysis
(G-RDA) (Lisitsyn et al., 1993). RAPD is a PCRbased marker technique which was introduced by Welsh and McClelland (1990) and Williams et al. (1990) in fingerprinting of plant genomes, while AFLP is a multi-locus-based marker technique which was developed in 1995 by Vos et al. These two techniques are very useful in identifying random polymorphisms in plant. However, the differences between the two compared genome will be based on the concept of either presence or absence of band with the expected size rather than directly identifying the differences in the DNA sequences (Voster et al., 2002). Whereas, the G-RDA technique is a PCR-based genomic subtraction technique which has been widely used to clone and sequence the difference in terms of genomic losses, point mutations, genomic rearrangements or amplifications between two closely related genomes. RDA is a unique method with combination of three elements: representation, subtractive hybridisation and kinetic enrichment (Lisitsyn et al., 1993). Representation refers to highly reproducible DNA samples that have been digested with appropriate restriction enzyme and ligated to oligonucleotide adaptors. Subtractive hybridisation involves mixing of two closely related genomes which have been cut into small fragments and ligated to adaptors. Kinetic enrichment is an enormous enrichment and purification of target sequence. The G-RDA also has the ability to scan a complexity of about $5 \times 10^{8}$ base pair of DNA and was first described by Lisitsyn et al. (1993). Since then, the G-RDA were applied in many research involving plant genome such as DNA enrichment in a maize chromosome addition line of oat (Chen et al., 1998), reveal genomic differences between oak species (Zoldos et al., 2001), characterisation of transposable element in the genome of rice (Panaud et al., 2002), characterisation of sequence differences between date palm varieties (Voster et al., 2002), genomic changes associated with somaclonal variation (Oh et al., 2007) and development of markers for mantled phenotype in oil palm (Cullis and Abdullah, 2007).

The specific aim of this study was to determine the genetic differences that are present between TLS and normal oil palm ramets using G-RDA method and also to generate potential biomarkers that can be useful in the identification of TLS plantlets at the early stage of tissue culture process. Thus, improving the oil palm tissue culture efficiency, reducing cost, labour and time.

\section{MATERIALS AND METHODS}

\section{Plant Materials and Genomic DNA Extraction}

The oil palm plantlets (Elaeis guineensis Jacq. form tenera) used was derived from tissue cultured material collected from the nursery of Felda 
Agricultural Services Sdn Bhd, Selangor, Malaysia. Two clones 1181 (severe and normal) and 2751 (mild and normal) were used as starting materials for genomic DNA extraction. Each clone has 20 replicates. The severity of the clones was classified based on Habib et al. (2012a). Genomic DNA was extracted from leaves or roots of oil palm using the method described by Dellaporta et al. (1983) with minor modification. The modification was at the final stage whereby DNA precipitation was performed overnight.

\section{Genomic-Representational Difference Analysis (G-RDA)}

In this study, G-RDA was carried out in two ways:

Forward RDA. The forward RDA was carried out using DNA from the abnormal ramets (TLS) as tester DNA and DNA from the normal ramets (wild type) as driver DNA. Here, only the unique sequences that were present in the tester DNA during the denaturation and re-association of DNA strands were amplified and the common sequences in both tester DNA and the driver DNA were eliminated.

Reverse RDA. The reverse RDA was carried out using DNA from the normal ramets (wild type) as tester DNA and DNA from the abnormal ramets
(TLS) as driver DNA, where the unique sequences in the driver DNA were amplified and the common sequences in both driver DNA and tester DNA were eliminated.

\section{Subtractive Hybridisation and Cloning}

Genomic RDA was carried out using the method described by Lisitsyn et al. (1993) with minor modifications. A total of $5 \mu \mathrm{g}$ genomic DNA (TLS and normal) were digested with $20 \mathrm{U}$ of restriction enzyme BamHI or BgllI (New England Biolabs, UK). Four rounds of subtractive hybridisation were carried out with a tester to driver DNA ratio of 1:1000, 1:10 000, 1:100 000 and 1:1 000000 for first, second, third and fourth rounds, respectively. The final subtractive hybridisation products were cloned into the yT\&A cloning vector (Invitrogen, USA) following the manufacturer's instructions and transformed into the DH5 $\alpha$ E. coli competent cells. Positive clones were selected via colony PCR and sequenced (Macrogene, China).

\section{Sequence Analysis}

The sequenced G-RDA clones (Table 1) were subjected to homology searches in the GenBank using the BLASTN (search a nucleotide database using a nucleotide query) and BLASTX (search a protein database using a nucleotide query) (http: / / www.ncbi.nlm.nih.gov / Blast).

TABLE 1. LIST OF FORWARD GENOMIC REPRESENTATIONAL DIFFERENCE ANALYSIS (G-RDA) CLONES OBTAINED FROM SEQUENCING RESULT

\begin{tabular}{|c|c|c|c|}
\hline Ramets type & Restriction enzyme & Clone & Length ${ }^{a}(b p)$ \\
\hline & & F4(1)-1181BamHI & 112 \\
\hline & & F4(2)-1181BamHI & 98 \\
\hline & & F4(3)-1181BamHI & 77 \\
\hline & & F4(6)-1181BamHI & 101 \\
\hline & BamHI & F4(10)-1181BamHI & 126 \\
\hline & & F4(14,16)-1181BamHI & 98 \\
\hline & & F4(15)-1181BamHI & 90 \\
\hline \multirow[t]{10}{*}{1181 (Forward G-RDA) } & & F4(17)-1181BamHI & 104 \\
\hline & & F4(19)-1181BamHI & 88 \\
\hline & & F4(4,14)-1181BglII & 159 \\
\hline & & F4(6)-1181BglII & 214 \\
\hline & BglII & F4(10)-1181BglII & 253 \\
\hline & & F4(12)-1181BglII & 133 \\
\hline & & F4(12.1)-1181BglII & 153 \\
\hline & & F4(13)-1181BglII & 164 \\
\hline & & F4(7.11.21)-2751BamHI & 111 \\
\hline & BamHI & F4(10)-2751BamHI & 87 \\
\hline \multirow[t]{4}{*}{2751 (Forward G-RDA) } & & F4(23)-2751BamHI & 151 \\
\hline & & F4(9)-2751BgIII & 403 \\
\hline & BglII & F4(12)-2751BglII & 434 \\
\hline & & F4(19)-2751BglII & 373 \\
\hline
\end{tabular}

Note: a The true length of G-RDA difference products after removal of oligonucleotide adaptor sequences. 


\section{Verification of Genomic RDA Products}

Primer design and PCR analysis. Pairs of primers were designed for the final RDA products using the primer3 Input Version 0.4.0 (http://www.frodo. wi.mit.edu/cgi-bin/primer3/primer3_www.cgi). The genomic DNA from normal and TLS ramets (1181-normal and severe type; 2751-normal and mild type) were used as template for PCR amplification. A PCR mixture containing $10 \mathrm{ng}$ of genomic DNA, $1 \times$ buffer for KOD hot start polymerase (Novagen, Germany), $1.5 \mathrm{mM} \mathrm{MgSO}_{4}$ (Novagen, Germany), 0.2 $\mathrm{mM}$ dNTPs (Novagen, Germany) , $0.3 \mu \mathrm{M}$ forward and $0.3 \mu \mathrm{M}$ reverse primers (Table 2), 0.2 units of KOD hot start polymerase (Novagen, Germany) in a total volume of $10 \mu \mathrm{l}$ was prepared. Amplification of PCR was performed for $2 \mathrm{~min}$ at $95^{\circ} \mathrm{C}$, followed by 35 cycles of $20 \mathrm{~s}$ at $95^{\circ} \mathrm{C}, 20 \mathrm{~s}$ depending on the annealing temperature of the primers, $15 \mathrm{~s}$ at $70^{\circ} \mathrm{C}$ and a final extension step of $10 \mathrm{~min}$ at $72^{\circ} \mathrm{C}$. The PCR products were separated on a $2.0 \%(\mathrm{w} / \mathrm{v})$ agarose gel, stained with ethidium bromide and visualised under UV light using a Gel Documentation System (Syngene, United Kingdom).

Verification through sequence analysis. Further analysis of the PCR products was done to identify the single nucleotide polymorphisms between the wild type and TLS oil palm ramets since the designed primers were not selective to the tester genome. The electrophoresed PCR products were excised and gel purified using a gel purification kit following the manufacturer's instruction (GeneAll, Korea). The gel purified PCR products were cloned following the same procedure described above and sequenced (Macrogene, China). The sequences were aligned (normal vs. TLS ramets, sequences) and compared using the BioEdit Sequence Alignment Editor Version 7.0.5.3 software.

Verification through PCR and southern analyses. A PCR reaction was carried out using the primer pairs which gave positive result (selective to tester genome) using genomic DNA of wild type and TLS oil palm ramets as template. The PCR reaction was carried out in a total volume of $20 \mu \mathrm{l}$, consisting of $10 \mathrm{ng}$ of genomic DNA, $1 \times$ buffer for KOD hot start polymerase (Novagen, Germany),

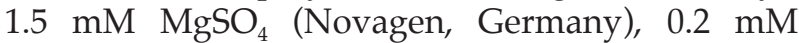
dNTPs (Novagen, Germany), $0.3 \mu \mathrm{M}$ forward and $0.3 \mu \mathrm{M}$ reverse primers (Table 2) and $0.2 \mathrm{U}$ of $\mathrm{KOD}$ hot start polymerase (Novagen, Germany). The cycling parameters were: $2 \mathrm{~min}$ at $95^{\circ} \mathrm{C}$, followed by 35 cycles of $20 \mathrm{~s}$ at $95^{\circ} \mathrm{C}, 20 \mathrm{~s}$ depending on the annealing temperature of the primers (Table 2), $15 \mathrm{~s}$ at $70^{\circ} \mathrm{C}$ and a final extension step of $10 \mathrm{~min}$ at $72^{\circ} \mathrm{C}$. The PCR products were separated on $2.0 \%(\mathrm{w} / \mathrm{v})$ agarose gel and transferred on positively charged nylon membrane (Amersham Biosciences, United
Kingdom). The labelling of probes and detection was performed as described by the manufacturer (Thermo Scientific, EU).

\section{RESULTS AND DISCUSSION}

\section{Genomic Representational Difference Analysis (G-RDA)}

Four rounds of subtractive hybridisation of forward and reverse G-RDA were performed using the genomic DNA from normal and TLS (1181 and 2751) ramets. Theoretically, any resulting bands should be unique to the tester genome only. After the fourth round of G-RDA, the isolated enriched unique sequences for forward and reverse G-RDA of 1181 (severe and normal) and 2751 (mild and normal) ramets were found to be in the range of approximately $180-500 \mathrm{bp}$ (Figures $1 \mathrm{a}$ to $1 \mathrm{~h}$ ). The final round of forward difference products were extracted from gel, cloned separately and randomly selected colonies were sequenced. The insert sizes matched the sizes of DNA profiles (180-500 bp) observed during subtractive hybridisation. The reverse G-RDA results were not subjected to any verification process. It is simply because of our aim and the early objective of this study is to identify the unique sequences that were present in TLS ramet which can be used as a biomarker in identifying the TLS ramets in the early stage of oil palm tissue culture process.

After eliminating those poor sequences, a total of 21 sequences (Table 1) were subjected to homology search with those available oil palm genomic sequences in the GeneBank database using the BLASTN programme. Only one of those sequences [F4(4.14)-1181BglII] had identity to a known gene, ycf2 from oil palm genome of Elaeis guineensis Jacq. The rest of the sequences gave poor hits to sequences in the GenBank database due to the small G-RDA product size $(\sim<500 \mathrm{bp})$. Moreover, a complete oil palm genome sequence was also not available in the public database at the time this work was performed. Hence, all the resulting sequences were sent to the Malaysian Palm Oil Board (MPOB, Malaysia) for further analysis to obtain longer fragments. Those sequences that were very short in length $(<200$ $\mathrm{bp}$ ) and do not match to any of the MPOB oil palm genomic sequences were not further investigated. As shown in Table 3, 18 out of 21 sequences were finally selected for verification.

\section{Primer Design and PCR Analysis}

Eighteen sets of primers (Table 2) were designed and used to amplify the expected size of PCR products from genomic DNA of normal and TLS ramet. Two primers, F4(6)-1181BgIII and F4(10)-1181BgIII revealed 
TABLE 2. OLIGONUCLEOTIDE PRIMER SEQUENCES USED IN VERIFICATION VIA POLYMERASE CHAIN REACTION (PCR) ANALYSIS

\begin{tabular}{|c|c|c|c|c|}
\hline Primer's name & $\operatorname{Tm}\left({ }^{\circ} \mathrm{C}\right)$ & Sequences $5^{\prime}-3^{\prime}$ & $\begin{array}{c}\text { Optimised } \\
\text { annealing } \\
\text { temperature }\left({ }^{\circ} \mathrm{C}\right)\end{array}$ & $\begin{array}{l}\text { Expected } \\
\text { size (bp) }\end{array}$ \\
\hline F4(1)-1181BamHI (F) & 61.1 & AGG TCA AGG GCG AAT TCG AGG & 59.3 & 502 \\
\hline F4(1)-1181BamHI (R) & 58.7 & TTG TCG CAG GAC CTT GTA GGC & & \\
\hline F4(1)-1181BamHI (NF) & 61.5 & CGC GAG ATC CGA CCA TGG TTA & 60.0 & 447 \\
\hline F4(1)-1181BamHI (NR) & 61.5 & CCC CAA GTG ATT CCC GCA AAT & & \\
\hline F4(2)-1181BamHI (F) & 60.4 & TCG GTT CTT TGA GAA AGA GGG CTT & 56.0 & 490 \\
\hline F4(2)-1181BamHI (R) & 54.7 & CAA AGT CTC TCT CAT GGC CTC TAT & & \\
\hline F4(3)-1181BamHI (F) & 57.9 & ATA GCT AGC CAC CTC TCT CCA GCT & 68.5 & 439 \\
\hline F4(3)-1181BamHI (R) & 57.9 & CGT ATC TGG GGT CCC CTT TTA TAG & & \\
\hline F4(10)-1181BamHI( F) & 59.0 & GCG GTG CTG GAA CTA ACC TAT TTC & 65.0 & 454 \\
\hline F4(10)-1181BamHI( R) & 60.8 & AGA GAG AGA TGG GCA CAA CCG AA & & \\
\hline F4(14,16)-1181BamHI (F) & 61.2 & TTT CTT ATC GTG GGT GGC TTC TCC & 70.0 & 431 \\
\hline F4(14,16)-1181BamHI (R) & 64.0 & AGC TGG CCG ATC TTC TCC TTC ACA & & \\
\hline F4(15)-1181BamHI (F) & 55.6 & GCC ACA ACT CTG CTC CAC TTT & 70.0 & 460 \\
\hline F4(15)-1181BamHI (R) & 67.9 & TGT TGG TGC AAA AAT CCA TCG GCG & & \\
\hline F4(15)-1181BamHI (NF) & 53.8 & CTG CTC CAC TTT CTG TAA CGG & 55.0 & 311 \\
\hline F4(15)-1181BamHI (NR) & 55.0 & CAA CAA GAA TGG AGT GCT CGA & & \\
\hline F4(17)-1181BamHI (F) & 69.8 & CGA GCT ATC CAA CGC CAT CCA AGT CCA & 69.4 & 539 \\
\hline F4(17)-1181BamHI (R) & 64.2 & GTC AAG TCC TCG GTG CAC GGG ATG CGA & & \\
\hline F4(17)-1181BamHI (NF) & 60.1 & AAA TAT CCG TGG GTG GAG CAT GAC CCG & 65.0 & 449 \\
\hline F4(17)-1181BamHI (NR) & 64.9 & ACG TCC GAA TCC CAC GAA GGC GGG ATG & & \\
\hline F4(19)-1181BamHI (F) & 65.1 & CGA TTC GTC ACC TCG ATA TTG GCG & 70.8 & 440 \\
\hline F4(19)-1181BamHI (R) & 62.8 & CAG CGA TTG ACA TTC CCT CGG A & & \\
\hline F4(4,14)-1181BgIII (F) & 60.3 & TGG CAA TTC CGT CAA GAT CTC TTC & 65.0 & 446 \\
\hline F4(4,14)-1181BgIII (R) & 55.8 & CTG TTC TCA TGT TTT GTG AAT AGC C & & \\
\hline F4(6)-1181BglII (F) & 53.8 & AGA ATA GGA GCC TTA TCA CTC TTG A & 53.7 & 502 \\
\hline F4(6)-1181BglII (R) & 54.7 & CCT ATA TTC TGG ATA TCC CTG CAC & & \\
\hline F4(10)-1181BgIII (F) & 65.3 & TTA TCT CCG ACT CCG GTG AGG TCT CTG & 60.0 & 579 \\
\hline F4(10)-1181BglII (R) & 66.5 & СТC TTT CСC CAC CTT TGG CTC TGA CTG & & \\
\hline F4(12)-1181BgIII (F) & 54.0 & GCA CCG TAC CCT TTA ACA ACA & 54.3 & 500 \\
\hline F4(12)-1181BglII (R) & 56.1 & CAT GCG ACA TAC GAC ACC AAG & & \\
\hline F4(12.1)-1181BgIII (F) & 54.0 & ATG AAG ATA ACC CTA TTG CTA GCC & 60.0 & 411 \\
\hline F4(12.1)-1181BglII (R) & 52.0 & TAG AAG ATA GAA GAG CCC AGA TTC & & \\
\hline F4(13)-1181BgIII (F) & 62.4 & ATG GCA AAA GAG TTG GGT GTT CGA & 63.5 & 499 \\
\hline F4(13)-1181BgIII (R) & 57.0 & CCC ATA GGG CGT ATT TAG TTT CTG & & \\
\hline F4(7.11.21)-2751BamHI (F) & 65.4 & TCA TTA TGG GAG CGA TCA CAC CGG & 59.8 & 617 \\
\hline F4(7.11.21)-2751BamHI(R) & 62.8 & CCA TGG CAG AAG AAA GAG ATC CCC & & \\
\hline F4(10)-2751BamHI (F) & 67.2 & TTC GGA TGG CAT GGG GAG GTT TG & 66.0 & 598 \\
\hline F4(10)-2751BamHI(R) & 62.3 & CCG AAC TCC TTT CGA ACT TCG TCA & & \\
\hline F4(10)-2751BamHI (NF) & 61.5 & GAC GTC AGA GGT GAT CGA TCG TTG & 62.9 & 544 \\
\hline F4(10)-2751BamHI(NR) & 62.1 & TTC GAG CTT CTT CGA CAA CGA GGT & & \\
\hline F4(12)-2751BgIII (F) & 57.8 & GAT GTC GCA CAT CCA GGA TCA & 60.0 & 678 \\
\hline F4(12)-2751BgIII (R) & 52.1 & GAC CTA AGG ATG TCA CAC ATC C & & \\
\hline F4(19)-2751BglII (F) & 67.0 & GAA GGA TGT CGC ACA TCC AGG ATC ATG & 67.5 & 682 \\
\hline F4(19)-2751BglII (R) & 62.8 & GAC CTA AGG ATG TCA CAC ATC CGA GAT C & & \\
\hline
\end{tabular}




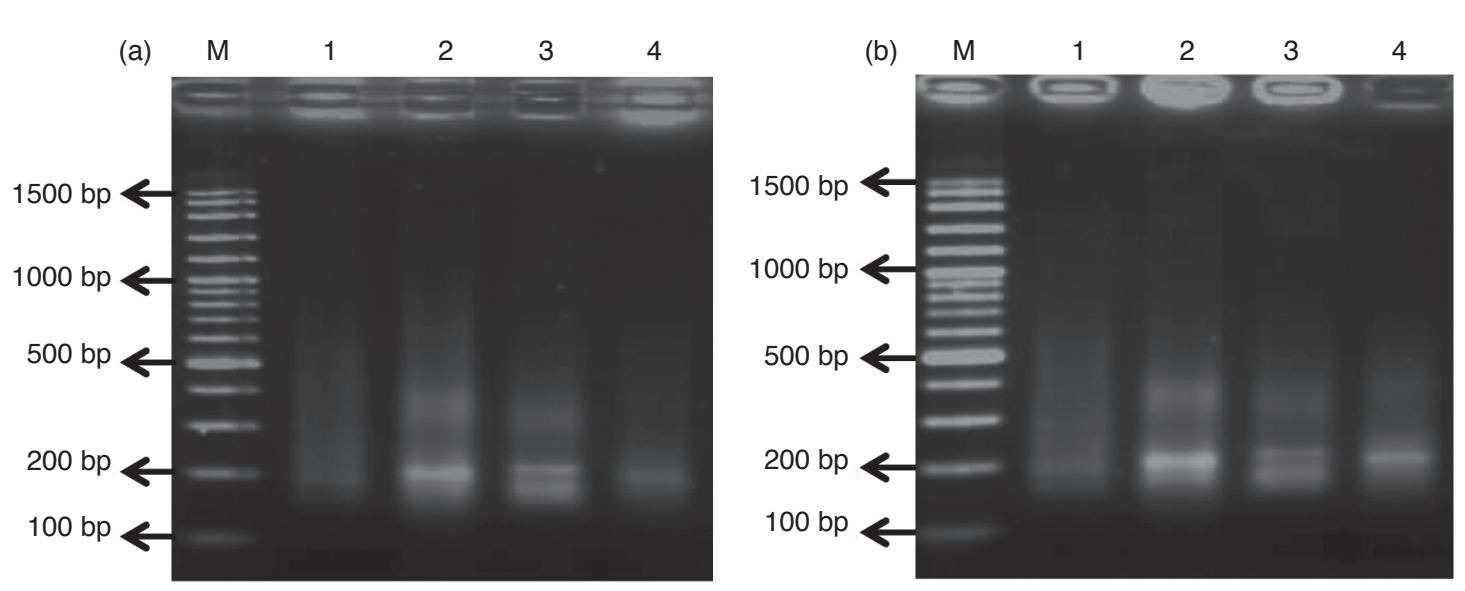

Figure 1( $a$ and $b$ ). The difference products obtained from forward and reverse Genomic Representational Difference Analysis (G-RDA) experiment of 1181 [normal and Truncated Leaf Syndrome (TLS)] using BamHI restriction enzyme (a) and electrophoresed on 2.0\% (w/v) agarose gel respectively. All the difference products were ligated to oligonucleotide adaptor sequences. Lane M contains 100 bp GeneRuler ${ }^{\mathrm{TM}}$ DNA ladder (Fermentas, Canada); lanes 1 to 4 contain first, second, third and fourth rounds of forward G-RDA respectively; lanes 5 to 8 contain first, second, third and fourth rounds of reverse $G-R D A$ respectively.
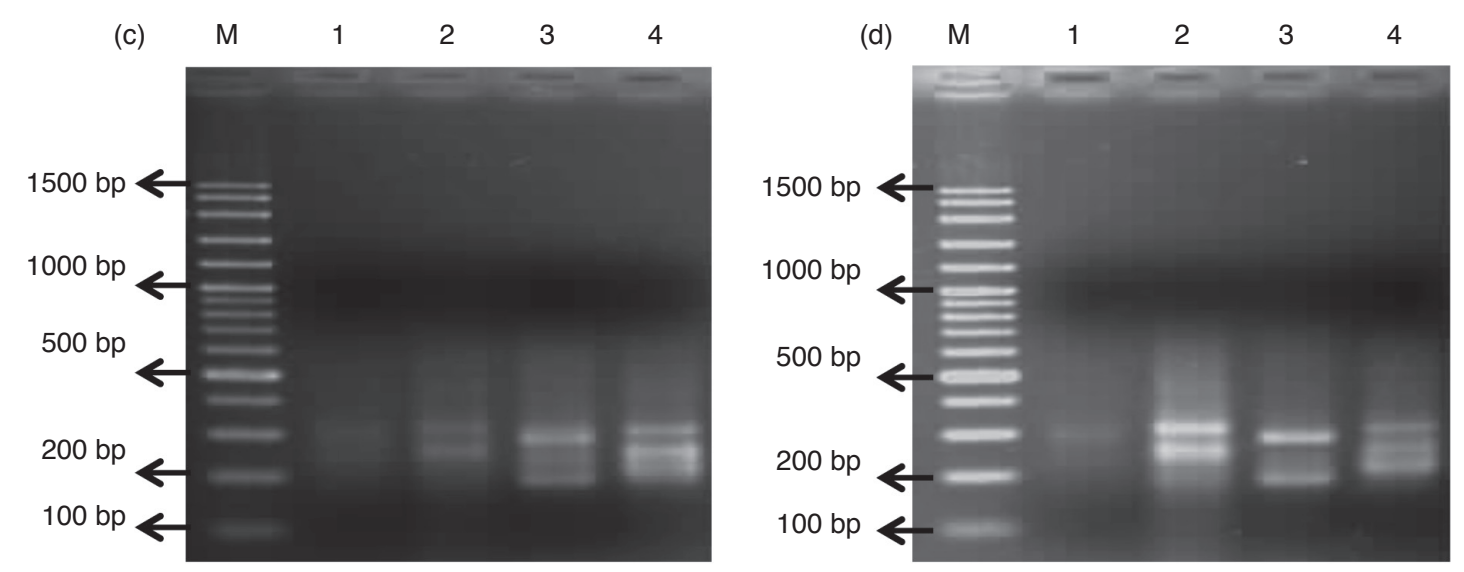

Figure 1(c and d). The difference products obtained from forward and reverse Genomic Representational Difference Analysis (G-RDA) experiment of 1181 [normal and Truncated Leaf Syndrome (TLS)] using BglII restriction enzyme and electrophoresed on 2.0\% (w/v) agarose gel respectively. All the difference products were ligated to oligonucleotide adaptor sequences. Lane M contains 100 bp GeneRuler ${ }^{\mathrm{TM}}$ DNA ladder (Fermentas, Canada); lanes 1 to 4 contain first, second, third and fourth rounds of forward G-RDA respectively; lanes 5 to 8 contain first, second, third and fourth rounds of reverse $G-R D A$ respectively.
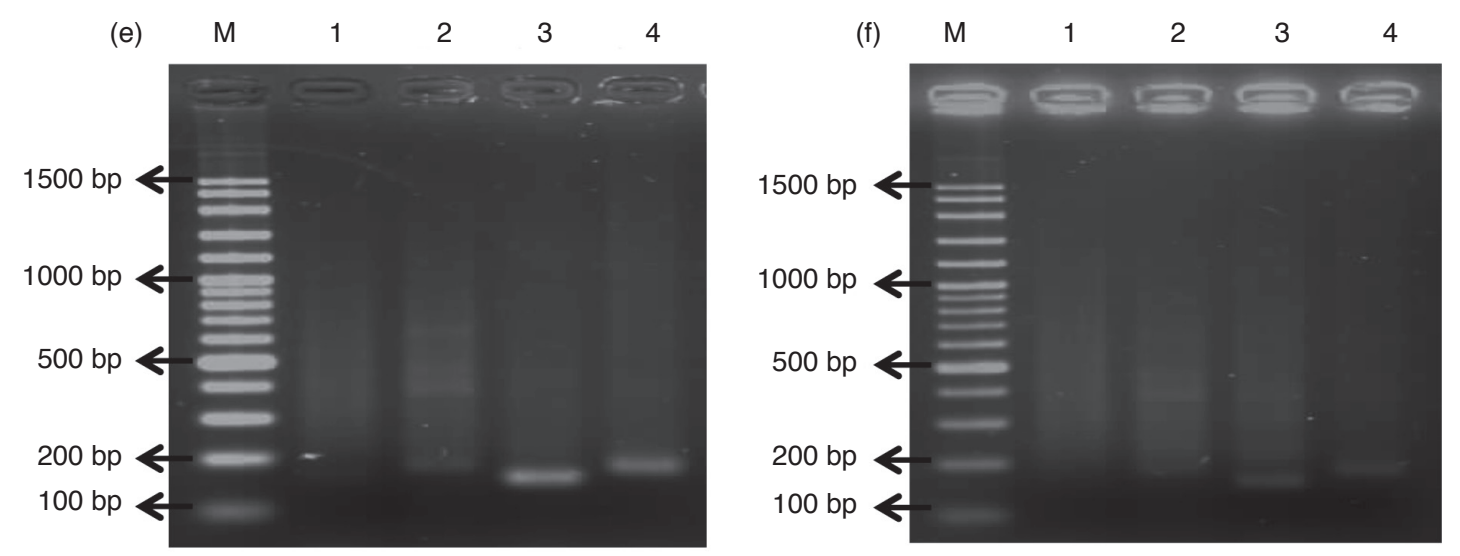

Figure 1(e and f). The difference products obtained from forward and reverse Genomic Representational Differences Analysis (G-RDA) experiment of 2751 [normal and Truncated Leaf Syndrome (TLS)] using BamHI restriction enzyme and electrophoresed on 2.0\% (w/v) agarose gel respectively. All the difference products were ligated to oligonucleotide adaptor sequences. Lane M contains 100 bp GeneRuler ${ }^{\mathrm{TM}}$ DNA ladder (Fermentas, Canada); lanes 1 to 4 contain first, second, third and fourth rounds of forward G-RDA respectively; lanes 5 to 8 contain first, second, third and fourth rounds of reverse G-RDA respectively. 



Figure $1(\mathrm{~g}$ and $\mathrm{h})$. The difference products obtained from forward and reverse Genomic Representational Difference Analysis (G-RDA) experiment of 2751 [normal and Truncated Leaf Syndrome (TLS)] using BglII restriction enzyme and electrophoresed on 2.0\% (w/v) agarose gel respectively. All the difference products were ligated to oligonucleotide adaptor sequences. Lane M contains 100 bp GeneRuler ${ }^{\mathrm{TM}}$ DNA ladder (Fermentas, Canada); lanes 1 to 4 contain first, second, third and fourth rounds of forward G-RDA respectively; lanes 5 to 8 contain first, second, third and fourth rounds of reverse $G-R D A$ respectively.

TABLE 3. LIST OF FORWARD GENOMIC REPRENSENTATIONAL DIFFERENCE ANALYSIS (G-RDA) CLONES HITS THAT TO MPOB OIL PALM SEQUENCES

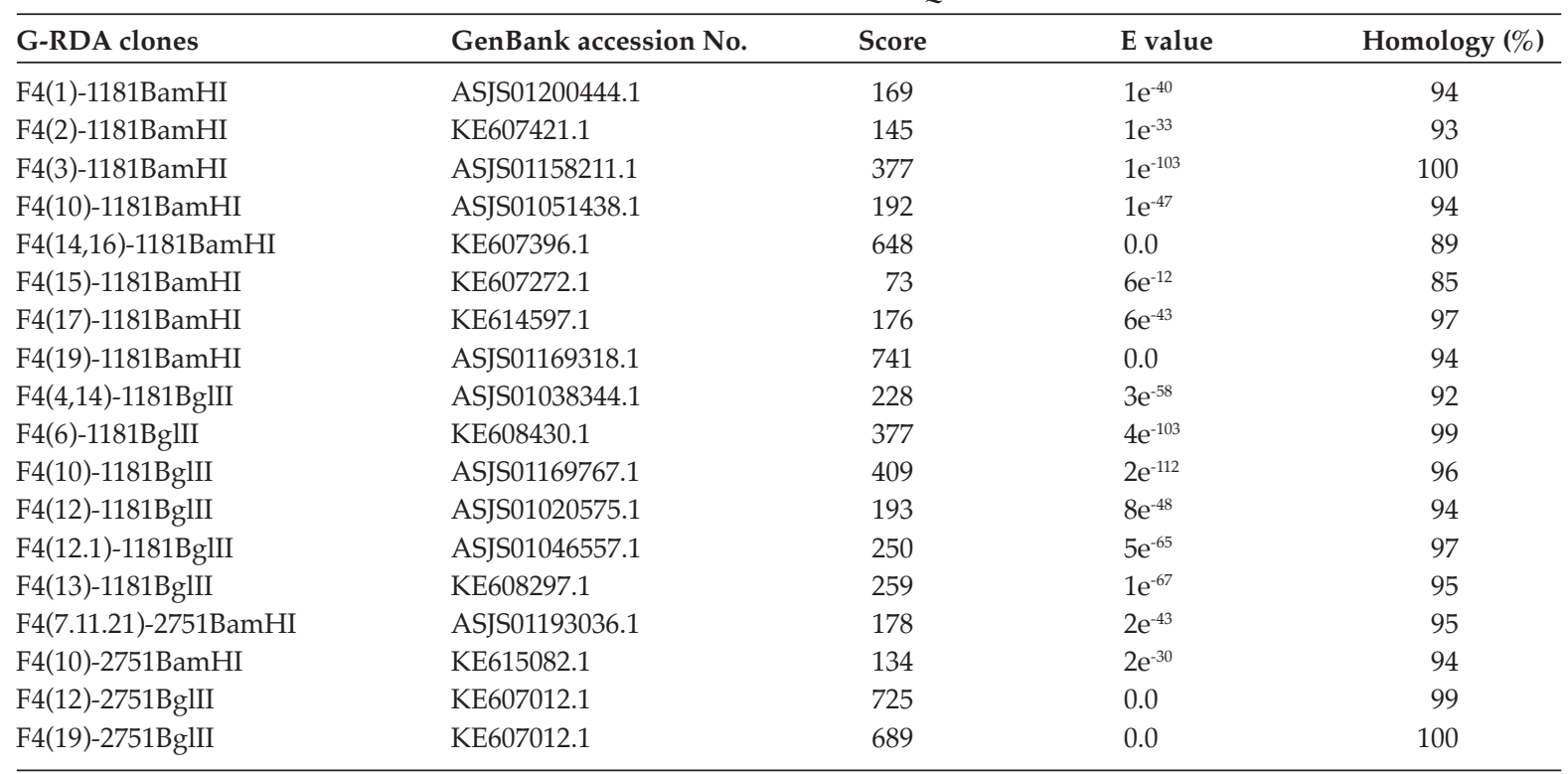

significant differences between the two compared genomes (Figure 2). The primer set, F4(6)-1181BglII amplified the predicted $502 \mathrm{bp}$ PCR product in TLS ramet but failed to amplify a fragment in normal ramet (indicated by circle in Figure 2a). On the other hand, primer set F4(10)-1181BglII amplified the predicted $579 \mathrm{bp}$ PCR product with an additional band of $480 \mathrm{bp}$ in normal ramet but failed to amplify the expected fragment in TLS ramet. However, this primer set amplified a $480 \mathrm{bp}$ PCR product in TLS ramet (indicated by circle in Figure 2b). The rest of the primer sets did not reveal any obvious size differences in the amplified product from the two compared genomes. Lack of differences could be due to minor base pair changes or single nucleotide deletion and or insertion that might have occurred in the two compared genomes. Thus, all the resulting PCR amplified products were sequenced for further verification.

\section{Sequence Verification}

The PCR products were cloned and sequenced to identify any differences in single nucleotide or base changes possibly caused by insertions, deletions or other genomic DNA rearrangements. The complete pair wise sequence comparisons were made between the PCR product sequences of 


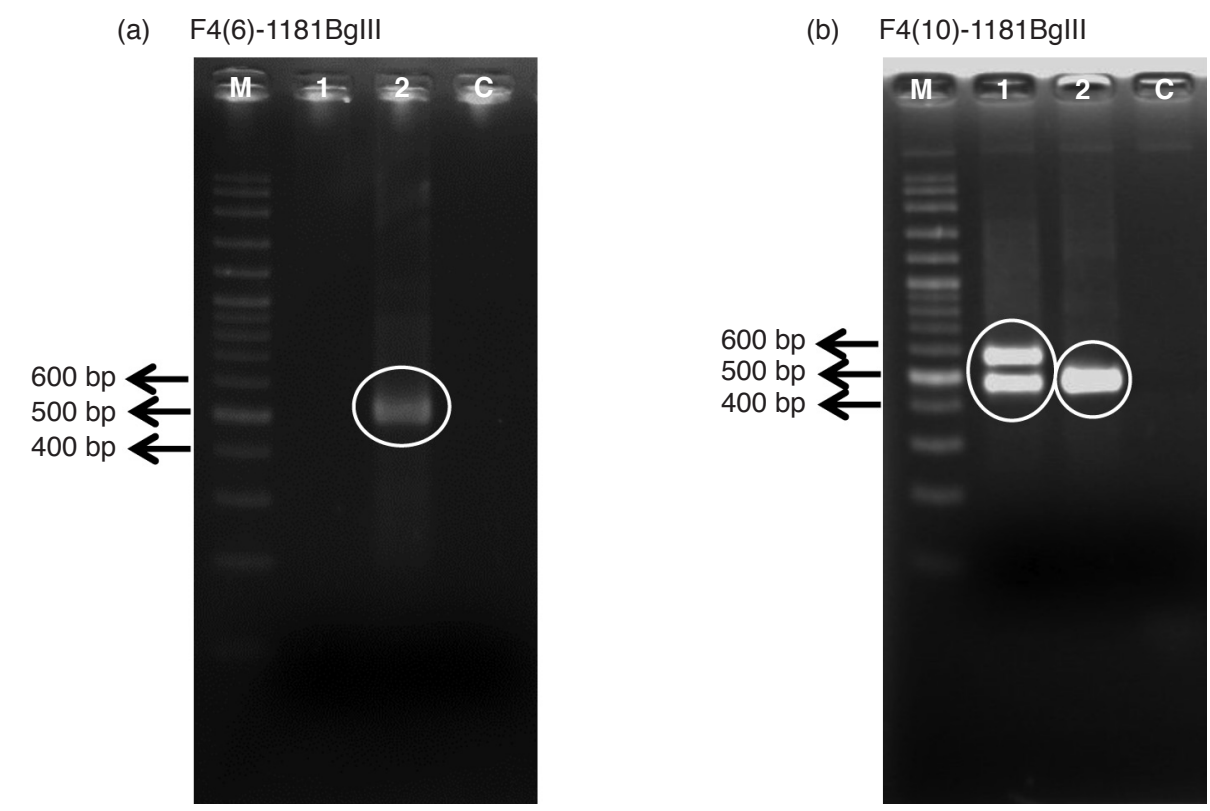

Figure 2. The polymerase chain reaction (PCR) products obtained with various sets of primers (Table 2) designed from the selected Genomic Representational Difference Analysis (G-RDA) difference products and electrophoresed on 2.0\% (w/v) agarose gel. Lane M: 100 bp GeneRuler ${ }^{\mathrm{TM}} \mathrm{DNA}$ ladder (Fermentas, Canada); lane 1: genomic DNA from normal; lane 2: genomic DNA from TLS; lane C: negative control (without template).

normal and TLS and the differences were scored as reported in Table 4.

Two primer sets, F4(12)-2751BgIII and F4(19)2751BglII showed no differences between the normal and TLS ramets (Table 4). This indicates that the region of difference product that was used to design primers is common to both the compared genome even though this difference product was supposed to be unique only to the TLS ramet. A possible explanation has been presented for these phenomena, where the fragments in the off-type or abnormal plants can be present in the normal plants but not all the fragments that are present in normal plants would be in the off-type or abnormal plants (Cullis and Kunert, 2000; Oh et al., 2007).
The sequence analysis of eight primer sets [F4(3)-1181BamHI, F4(10)-1181BamHI, F4(14,16)1181BamHI, F4(17)-1181BamHI, F4(19)-1181BamHI, F4(13)-1181BglII and F4(7,11,21)-2751BamHI] revealed minor nucleotide or base changes in normal ramet when compared to their respective TLS ramet $(<10 \%$, Table 4$)$. A potential biomarker need to have very high sensitivity and specificity, which is at least $90 \%$ or more (Ziogas, 2011; Brower, 2011). Other than that, the eight primer sets were deemed as not potential biomarkers as they were only able to identify less than $10 \%$ nucleotide differences between the normal and TLS ramet. Phillips et al. (1994) suggested that nucleotide or base changes in sequences are the most common

TABLE 4. THE SUMMARY OF NUCLEOTIDE DIFFERENCES BETWEEN TRUNCATED LEAF SYNDROME (TLS) AND NORMAL GENOME OF RESPECTIVE PRIMERS SETS

\begin{tabular}{|c|c|c|c|}
\hline Primers sets & $\begin{array}{l}\text { Length } \\
\text { (bp) }\end{array}$ & $\begin{array}{l}\text { Nucleotide differences }{ }^{a} \\
\text { (bp) }\end{array}$ & $\begin{array}{c}\text { Nucleotide differences }{ }^{\mathrm{a}} \\
(\%)\end{array}$ \\
\hline F4(3)-1181BamHI & 439 & 40.0 & 9.11 \\
\hline F4(14,16)-1181BamHI & 431 & 17.0 & 3.94 \\
\hline F4(17)-1181BamHI & 449 & 8.0 & 1.78 \\
\hline F4(10)-1181BglII & 576 & 103 & 17.88 \\
\hline F4(10)-1181BglII & 473 & 0.0 & 0.00 \\
\hline F4(13)-1181BglII & 499 & 10.0 & 2.00 \\
\hline F4(7.11.21)-2751BamHI & 617 & 2.0 & 0.32 \\
\hline
\end{tabular}

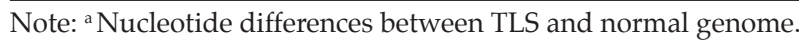


point mutation observed in tissue cultured plants. Theoretically, single nucleotide or base changes will be resulting in a $C$ to $T$ or $G$ to $A$ (deamination of methylated cytosine) transition which can lead to the elimination of functional gene products of those sequences (Phillips et al., 1994). In this case, the most commonly observed single nucleotide or base changes is from $\mathrm{T}$ to $\mathrm{C}$ or A to G. As such, those sequences derived from these eight primer sets might be unlikely to repr esent the major cause of the abnormality that present in the TLS ramet.

Primer set F4(6)-1181Bgl showed major differences in between the normal and TLS ramet $(100 \%$, Table 4). This primer set was able to amplify the expected size of 502 bp only from the genomic DNA of TLS ramet which is identical to that of the final subtracted hybridisation product and unable to produce any bands in the normal ramet. This could be due to the presence of large genetic differences between the two compared genomes which prevented the primer set F4(6)-1181BglII to bind and amplify the targeted region in the genome of normal ramet.

The primer set F4(10)-1181BgIII revealed differences due to deletion of approximately 100 base pair mainly in the $5^{\prime}$ region of the TLS genome (Figure 3). All the three sequences retain the same forward and reverse primer as well as the same final round of G-RDA difference product sequences. This simply means that the region that was used to design the primer set F4(10)-1181BglII, is common to more than one repetitive sequences in normal ramet compared to the TLS ramet. It is unclear whether the absence of the extra region in the TLS genome might be a cause to this abnormality.

The rest of the tested primer sets showed a false positive result. The choices of tester to driver DNA ratio play an important role in the subtractive hybridisation step, where poorly chosen ratio could result in the subtraction of false positive difference product. A relatively high difference in tester to driver DNA ratio could possibly reduce the efficiency as far as $100 \%$ of targeted DNA enrichment (Cho and Park, 1998; Milner et al., 1995).

The resulting sequence analysis has indicated that the variations between the two tested oil palm genomes were due to single nucleotide substitution or an insertion or a deletion of a portion of sequences in either in the normal or TLS genome.

\section{Verification through PCR and Southern Analyses}

The PCR products of two primer sets [F4(6)1181BglII and F4(10)-1181BglII] that showed significant differences between the two compared genomes (TLS and normal type) were identified as potential markers and have been further verified through PCR and Southern analysis with respect to their presence in 12 clones from different categories of TLS ramets (Table 5) and the resulting gel photographs of PCR product are shown in Figure $4[a(\mathrm{I}), b(\mathrm{I}), c(\mathrm{I}), d(\mathrm{I}), e(\mathrm{I})$ and $f(\mathrm{I})]$. The Southern hybridisation technique confirmed the presence of selected region (in this case the sequences of the final round of G-RDA product) along with a positive control (Panaud et al., 2002). The subtractive hybridisation product of F4(6)-1181BgIII and F4(10)$1181 \mathrm{Bg}$ III was used as a probe in Southern blot analysis against the PCR products and the resulting X-ray films are shown in Figure $4[a(\mathrm{II}), b(\mathrm{II}), c(\mathrm{II})$, $d(\mathrm{II}), e(\mathrm{II})$ and $f(\mathrm{II})]$ respectively.

As shown in Figure 4, the normal and TLS ramet from clone 1181 is the only pair that is distinguishable using the primer set F4(6)-1181BglII [lane 1 indicated by circle in Figure $4 a$ (I) and (II)]. This result suggests that the region corresponding to the probe used for hybridisation is absent exclusively in the normal ramet of clone 1181. This could be due to the differences in the plant genotype for each respective clone (Panaud et al., 2002; Zoldos et al., 2001). As shown in Table 5, only the paternal palm of clone 1181 was derived from the variety of Yangambi unlike the rest of the clones. Oil palm ramets that are derived from different varieties will possess different genomic sequences. Therefore, in future, the starting material and the samples for verification should include a range of variety to elucidate whether or not the designed primer can be used as a candidate biomarker to detect the TLS occurrence across various genotypes.

The primer set F4(10)-1181BglII showed a complex hybridisation pattern among the 12 clones tested as shown in Figures $4 d, 4 e$ and $4 f$. The first hybridisation pattern showed the presence of double bands in normal and single band in TLS genome while the second pattern showed the presence of single band in normal and double bands in TLS genome. The third and the fourth one have double bands and single band in both the normal and TLS genomes, respectively.

The primer set F4(10)-1181BglII showed similar hybridisation pattern in clone 2751 [Lanes 19 and 20 indicated by circle in Figure $4 f$ (I and II)] and clone 1181 [lanes 1 and 2 indicated by circle in Figure 4d (I and II)] with the presence of double bands in normal and single band in TLS ramet. Even though paternal palms for both the clones (1181 and 2751) are from different genotypes which are Yangambi and La Me respectively, they still show an identical banding pattern to each other. This occurrence can be understood better if a large number of clones from Yangambi and La Me varieties are tested during the verification process. If the results are reproducible in both the Yangambi and La Me variety, these primer set can be possibly used as a potential marker for these genotypes to identify the presence of TLS ramets at the early stage of oil palm tissue culture. 
1181Bgl_10 NORM $1181 \mathrm{Bgl} 10$ NORM 1181Bgl_10 TLS

$1181 \mathrm{Bgl} 10$ NORM $1181 \mathrm{Bgl} 10$ NORM 1181Bgl_10 TLS

1181Bgl_10 NORM $1181 \mathrm{Bgl} 10$ NORM 1181Bgl_10 TLS

1181Bgl_10 NORM $1181 \mathrm{Bgl} 10$ NORM 1181Bgl_10 TLS

1181Bgl_10 NORM $1181 \mathrm{Bgl} 10$ NORM 1181Bgl_10 TLS

$1181 \mathrm{Bg} 110$ NORM $1181 \mathrm{Bgl} 10$ NORM 1181Bgl_10 TLS

1181Bgl_10 NORM $1181 \mathrm{Bgl} 10$ NORM 1181Bgl_10 TLS

1181Bgl_10 NORM $1181 \mathrm{Bgl}-10$ NORM 1181Bgl_10 TLS

1181Bgl_10 NORM $1181 \mathrm{Bgl} 10$ NORM 1181Bgl_10 TLS

1181Bgl_10 NORM $1181 \mathrm{Bgl} 10$ NORM 1181Bgl_10 TLS

$1181 \mathrm{Bgl} 10$ NORM 1181Bgl_10 NORM 1181Bgl_10 TLS

1181Bgl 10 NORM $1181 \mathrm{Bgl} 10$ NORM 1181Bgl_10 TLS
10

20 $1 \ldots|\ldots| \ldots|\ldots|$

TTATCTCCGA CTCCGGTGAG GTCT TTGGTA AGAATTTGAA GCAAACACAA TTATCTCCGA CTCCGGTGAG GTCTETGGTA AGAATTTGAA GCAAACA--TTATCTCCGA CTCCGGTGAG GTCTFTGGTA AGAATTTGAA GCAAACA---

$\ldots|\ldots| \ldots|\ldots| \ldots|\ldots| \ldots|\ldots| \ldots|\ldots| \ldots|\ldots|$

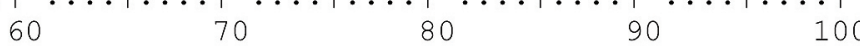

AGACGGCATC GGCAACTTCA ACGAAAAAAT TCAAGAGAAA AAAAAGGGAG


AACTTGATGC CCGCCGTGGC TGGCTATGGA GGAGGAAGGA AAAATTTTTA

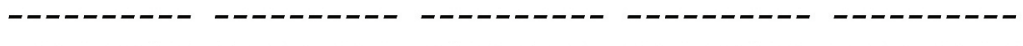

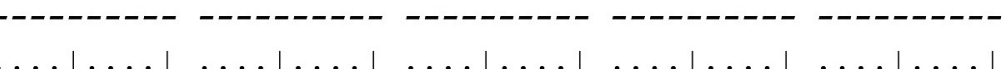

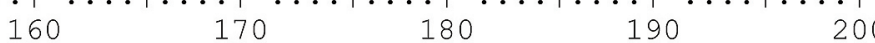

CAAAGACGGC ATCGGCAACT TCAACGAAAA AATTCAAGAG AAAAAAGAGG



CAAAGAGGGC ATCGGCAACT TCAACGGAAA AATCGAGA AAAAAAGAg

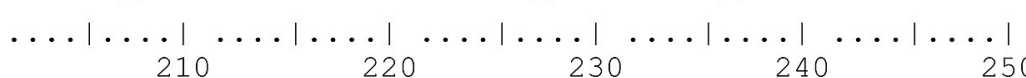

GAGAACTTGA TGCCCGCCGT GGCTGACTAT GGAGGAGGAA GGAAAAATTT GAGAACTTGA TGCCCGCCGT GGCTGGCTAT GGAGGAGGAA GGAAAAATTT GAGAACTTGA TGCCCGCCGT GGCTGĞCTAT GGAGGAGGAA GGAAAAATTT $\ldots|\ldots| \ldots|\ldots| \ldots|\ldots| \ldots|\ldots| \ldots|\ldots| \ldots|\ldots|$ $260 \quad 270 \quad 280 \quad 290 \quad 300$

TATAgGACTC TTCCTAGgGT TCCTATTTGC CCTAAAAATC CTTGATCtAG TATAGGACTC TTCCTAGGGT TCCTATTTGC CCTAAAAATT CTTGATCTAG TATAGGACTC TTCCTAGGGT TCCTATTTGC CCTAAAAATT CTTGATCTAG $\ldots|\ldots| \ldots|\ldots| \ldots|\ldots| \ldots|\ldots| \ldots|\ldots| \ldots \mid$ $\begin{array}{lllll}310 & 320 & 330 & 340 & 350\end{array}$ TCGGATACGG AGAGGAGGAA GAAGAAGACT CTCGAGTCTT TGTTCATTCT TCGGATACGG AGAGGAGGAA GAAGAAGACT CTCGAGTCTT TGTTCATTCT TCGGATACGG AGAGGAGGAA GAAGAAGACT CTCGAGTCTT TGTTCATTCT

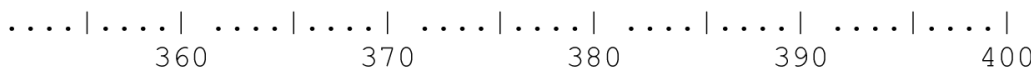
TTTTTTTTTT TTAACCATGA GCTTGATGGG CCAAAATCGA GTGGGCTTGA TTTTTTTTTT - TAACCATGA GCTTGATGGG CCAAAATCGA GTGGGCTTGA TTTTTTTTT -TAACCATGA GCTTGATGGG CCAAAATCGA GTGGGCTTGA


TTTTTAGAAC AGGGTATTAC AGCATCAGTT CGgAATGGAT TGGATCCTGG TTTTTAGAAC AGGGTATTAC AGCATCAGTT CGGAATGGAT TGGATCCTGG TTTTTAGAAC AGGGTATTAC AGCATCAGTT CGGAATGGAT TGGATCCTGG $\ldots|\ldots|_{460} \ldots|\cdots|_{470} \ldots|\cdots|_{480} \ldots|\cdots|_{490} \ldots|\cdots|_{500}$ ATATAACATC AAAgGTATAA TCTCATTGAT GTTCCAAAAg AgAACCATCT ATATAACATC AAAGGTATAA TCTCATTGAT GTTCCAAAAG AGAACCATCT ATATAACATC AAAgGTATAA TCTCATTGAT GTTCCAAAAg AgAACCATCT $\ldots|\ldots| \ldots|\ldots| \ldots|\ldots| \ldots|\ldots| \ldots|\ldots|$

$$
510 \quad 520 \quad 530 \quad 540
$$

\begin{tabular}{|c|c|c|}
\hline$\ldots|\ldots|$ & $\begin{array}{r}\ldots|\ldots| \\
57\end{array}$ & .1. \\
\hline AGTCAGAGCC & AAAGGTGGGG & AAAGAG \\
\hline AGTCAGAGCC & AAAGGTGGGG & AAAGAG \\
\hline AGTCAGAGCC & AAAGGTGGGG & AAA \\
\hline
\end{tabular}

TTCTATTGTT TATCCTGATA AAGTGCTGGG ATATCTGTGC TGGTAAAATC

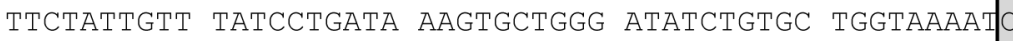

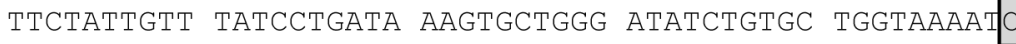

Figure 3. The comparison of nucleotide sequences of the polymerase chain reaction (PCR) amplified products using $1181 B g l$ (10) primer set and 1181 [normal and Truncated Leaf Syndrome (TLS)] genomic DNA as template. Mismatched nucleotides or different nucleotides are bolded with red font and underlined, presence of extra region is bolded and italicised, while primer sequences are boxed and shaded. 


\begin{tabular}{|c|c|c|c|}
\hline \multirow[t]{2}{*}{ Clone No. } & \multirow{2}{*}{$\begin{array}{l}\text { Genotype } \\
\left(\text { 우 } x 0^{* 1}\right)\end{array}$} & \multicolumn{2}{|c|}{ Classification } \\
\hline & & Abnormal & Normal \\
\hline 1181 & Deli Dura x Yangambi & Severe & Normal \\
\hline 1077 & Deli Dura x Dumpy & Severe & Normal \\
\hline 5313 & Deli Dura x Dumpy & Severe & Normal \\
\hline $5074 \mathrm{c}$ & Deli Dura x Dumpy & Severe & Normal \\
\hline 4807 & Deli Dura x Dumpy & Sever & Normal \\
\hline 4874 & Deli Dura x Dumpy & Severe & Normal \\
\hline 1072 & Deli Dura x Dumpy & Moderate & Normal \\
\hline 1073 & Deli Dura x Avros & Moderate & Normal \\
\hline 2818 & Deli Dura x Dumpy & Moderate & Normal \\
\hline 2751 & Deli Dura x La Me & Mild & Normal \\
\hline 1096 & Deli Dura x Dumpy & Mild & Normal \\
\hline 5099 & Deli Dura x Dumpy & Mild & Normal \\
\hline
\end{tabular}

Note: $\$$ - Female. $0^{\prime \prime}$ - Male.

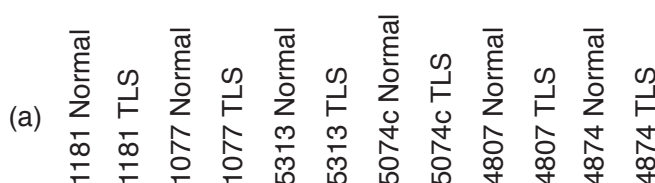

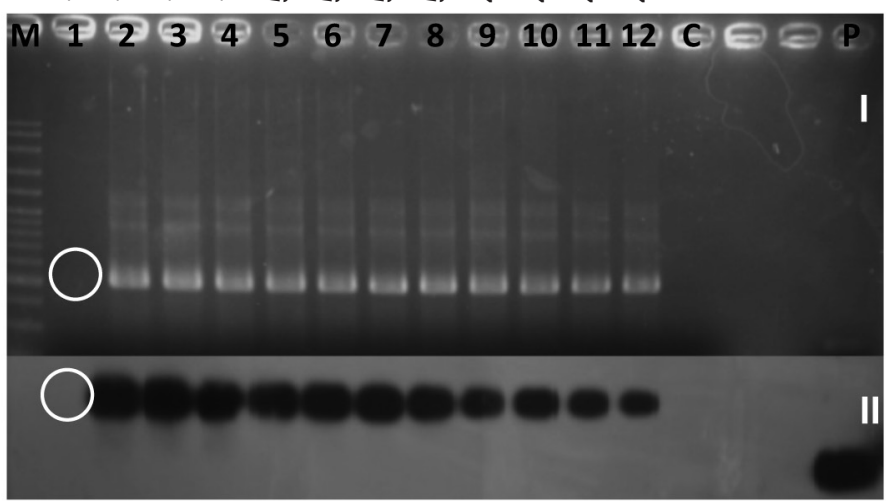

F4(6)-1181BgIII (Normal and Severe TLS)

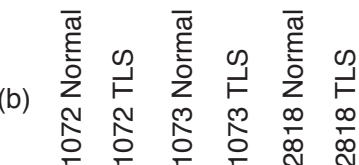

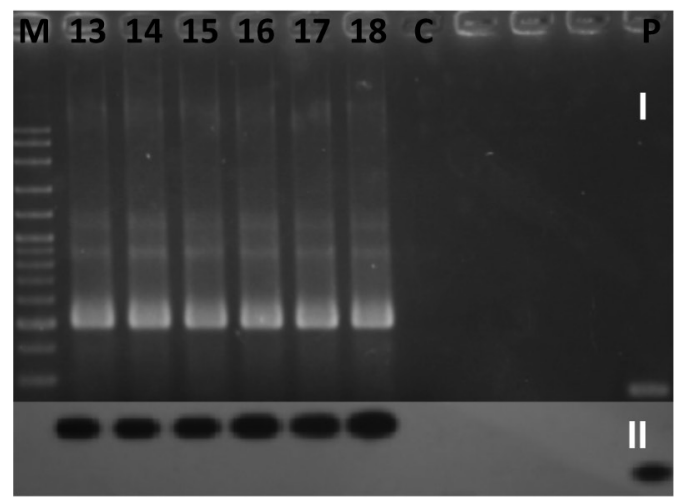

F4(6)-1181BgIII (Normal and Moderate TLS)

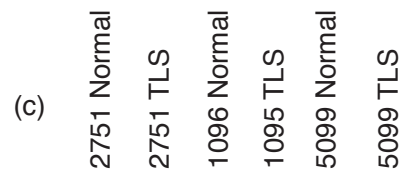

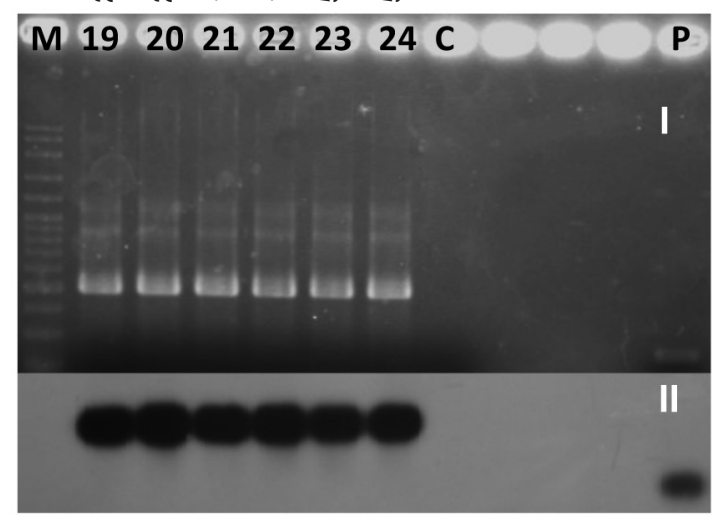

F4(6)-1181BgIII (Normal and Mild TLS)

Figure 4 ( $a, b$ and c). Polymerase chain reaction (PCR) and Southern analysis of forward Genomic Representational Difference Analysis (G-RDA) using F4(6)-1181BglII primer set. (I) PCR amplified insert DNA from individual oil palm ramets electrophoresed on 2.0\% (w/v) agarose gel. (II) Autoradiograph of a Southern analysis result containing the same DNA as shown in (I) that was hybridised with biotin-labelled F4(6)-1181BglII G-RDA difference product. Lane M: 100 bp GeneRuler ${ }^{\mathrm{TM}}$ DNA ladder (Fermentas, Canada); lanes 1, 3, 5, 7, 9, 11, 13, 15, 17, 19,21 and 23: Genomic DNA from normal oil palm ramets (Table 5); lanes 2, 4, 6, 8, 10, 12, 14, 16, 18, 20, 22 and 24: Genomic DNA from Truncated Leaf Syndrome (TLS) oil palm ramets (Table 5); lane C: Negative control (without template); lane P: positive control (product of final round of respective G-RDA). 


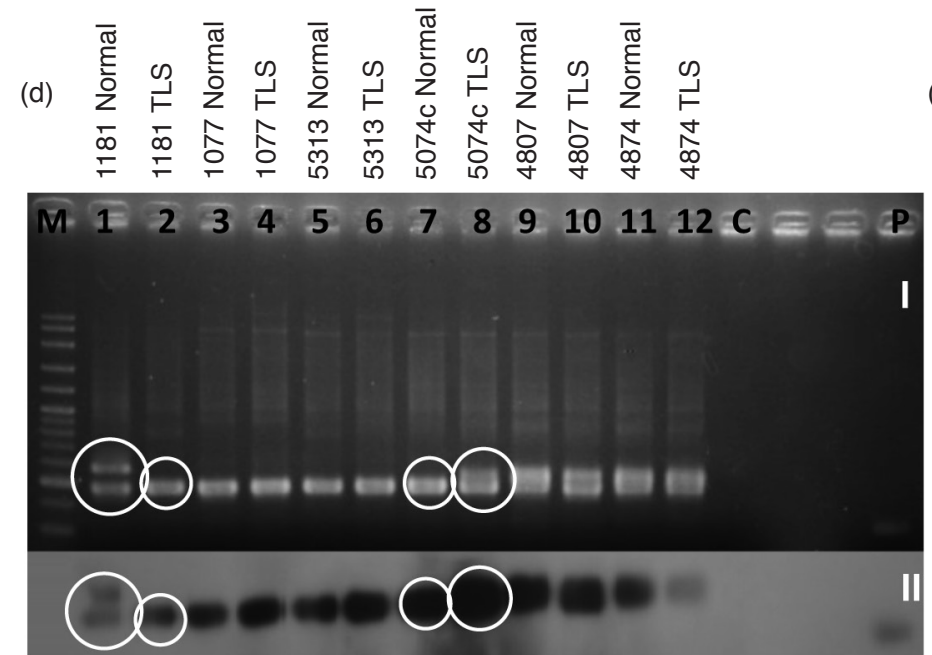

F4(10)-1181BgIll (Normal and Severe TLS)



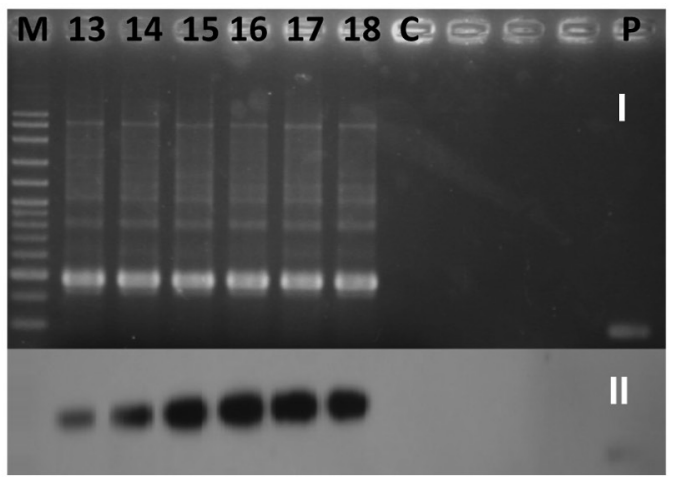

F4(10)-1181BgIll (Normal and Moderate TLS)

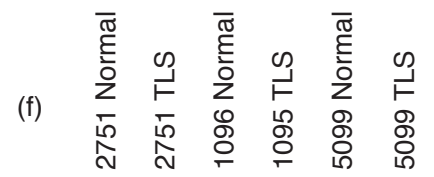

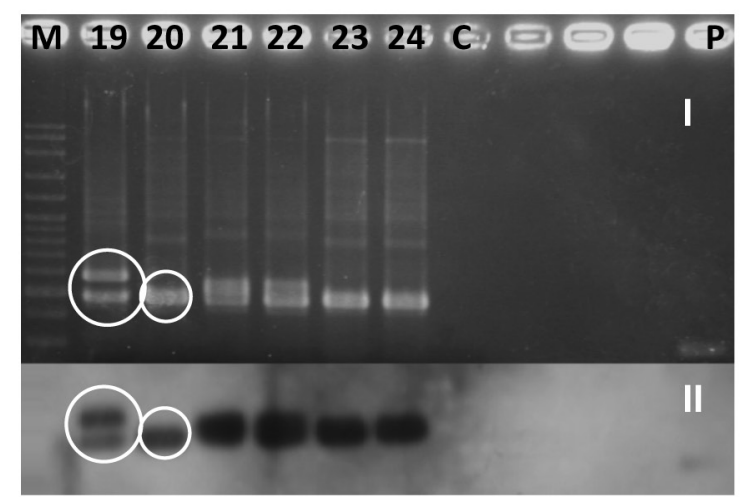

F4(10)-1181BgIII (Normal and Mild TLS)

Figure 4 (d, e and f). Polymerase chain reaction (PCR) and Southern analysis of forward Genomic Reprentational Difference Analysis (G-RDA) using F4(10)-1181BglII primer set. (I) PCR amplified insert DNA from individual oil palm ramets electrophoresed on 2.0\% (w/v) agarose gel. (II) Autoradiograph of a Southern analysis result containing the same DNA as shown in (I) that was hybridised with biotin-labelled F4(10)-1181BglII G-RDA difference product. Lane M: 100 bp GeneRuler ${ }^{\text {TM }}$ DNA ladder (Fermentas, Canada); lanes 1, 3, 5, 7, 9, 11, 13, 15, 17, 19, 21 and 23: genomic DNA from normal oil palm ramets (Table 5); lanes 2, 4, 6, 8, 10, 12, 14, 16, 18, 20, 22 and 24: Genomic DNA from TLS oil palm ramets (Table 5); lane C: negative control (without template); lane P: positive control (product of final round of respective G-RDA).

The clone 5074c showed the opposite result as compared to the clones 1181 and 2751 with primer set F4(10)-1181BgIII [lanes 7 and 8 indicated by circle in Figure 4d (I and II)] with the presence of single band in normal and double band in TLS ramet. On the other hand, three clones showed the presence of double bands in both normal and TLS ramet (4807, 4874 and 1096) as shown in both gel photograph and X-ray film [lanes 9, 10, 11, 12, 21 and 22 in Figures $4 d$ and $4 f$ (I and II)]. The rest of the clones $(1077,5313$, 1072, 1073, 2818 and 5099) showed the presence of single band in both TLS and normal ramet [lanes 3 , $4,5,6,13,14,15,16,17,18,23$ and 24 in Figures $4 d, 4 e$ and $4 f(\mathrm{I}$ and II)].

The presence of complex hybridisation pattern suggests that the hybridised probe detected several bands that could represent various types of repeated sequences and the variation in size would than corresponds to polymorphisms (Zoldos et al., 2001). Pluhar et al. (2001) reported that the presence of various types of repeated sequences might be due to the genome stress induced in tissue culture 
process (Vorster et al., 2002). The components in culture media and the type of explants used to generate tissue culture plantlets are some of the inducing factors for somaclonal variation (Leva et al., 2012). An imbalanced concentration of growth regulators such as auxins and cytokinins may induce polyploidy in tissue culture regenerants (Swartz, 1991). Endopolyploidy, polyteny and amplification or diminution of DNA sequences are the genome changes that can occur during somatic differentiation in callus culture of plantlets (D'Amato, 1977). Both qualitative and quantitative changes in plant genome can happen during dedifferentiation and redifferentiation process which can cause amplification or deletion of DNA sequences (D'Amato, 1977). Phillips et al. (1994) reported that tissue culture process may induce disruption in cellular control that leads to the changes in the number of repeated sequences present in tissue culture regenerants. These changes are most likely affected by mitotic recombination which results in either gain or loss of genetic information.
The banding patterns observed in Figure $4(d, e$, and $f$ ) were not consistent among the tested samples. Hence, PCR products of chosen oil palm clones that showed complex hybridisation pattern (1181, 5074c and 4807) were sequenced and alignment result (Figure 5) revealed that those sequences represent multiple regions within the same genome.

Even if there is no consistent difference detected between the normal and TLS genomes, most primer sets were able to differentiate between individual region of normal and TLS oil palm ramet. Since, the oil palm genome is large, 1.8 gigabase (Singh et al., 2013); the use of other additional restriction enzymes would provide more genomic subset for successful subtractive hybridisation. Furthermore, a new tester to driver ratio with preferable range combination would be useful to avoid false positive results. Even though there are some modification steps required in G-RDA, it remains a very useful tool for isolating, cloning and characterising the differences between two complex genomes.

$\begin{array}{llll}1181 & \text { NORMAL } & (473 \mathrm{bp}) \\ 1181 & \text { NORMAL } & (576 \mathrm{bp}) \\ 1181 & \text { TLS } & (473 \mathrm{bp}) \\ 5074 \mathrm{C} & \text { NORMAL } & (472 \mathrm{bp}) \\ 5074 \mathrm{C} & \text { TLS } & (472 \mathrm{bp}) \\ 5074 \mathrm{C} & \text { TLS } & (512 \mathrm{bp}) \\ 4807 & \text { NORMAL } & (472 \mathrm{bp}) \\ 4807 & \text { NORMAL } & (512 \mathrm{bp}) \\ 4807 & \text { TLS } & (472 \mathrm{bp}) \\ 4807 & \text { TLS } & (512 \mathrm{bp})\end{array}$

1181 NORMAL (473 bp)

1181 NORMAL (576 bp)

1181 TLS (473 bp)

$5074 c$ NORMAI (472 bp)

5074c TLS (472 bp)

$5074 \mathrm{C}$ TLS (512 bp)

4807 NORMAI (472 bp)

4807 NORMAL (512 bp)

4807 TLS (472 bp)

4807 TLS (512 bp)

\begin{tabular}{|c|c|}
\hline$\left.\left.\cdots|\cdots|_{10} \cdots\right|_{10}\right|_{20}$. & $\cdot \frac{1}{30} \cdot \cdots$ \\
\hline GA & \\
\hline GA CTCCGG & GTA \\
\hline $\mathrm{GA}$ CT & $A G$ \\
\hline $\mathrm{BA}$ CTC & GTA AC \\
\hline AG GT & GTA AC \\
\hline GA CTC & GTA AC \\
\hline $\mathrm{GA}$ CTC & GTA AG \\
\hline GA CTCCGGTGAG GTCT & GTA AG \\
\hline GA CTCCGG' & GTA AC \\
\hline TATCTCCGA CTCCGGTGAG GTCTC & $\mathrm{AA}$ GCAF \\
\hline
\end{tabular}

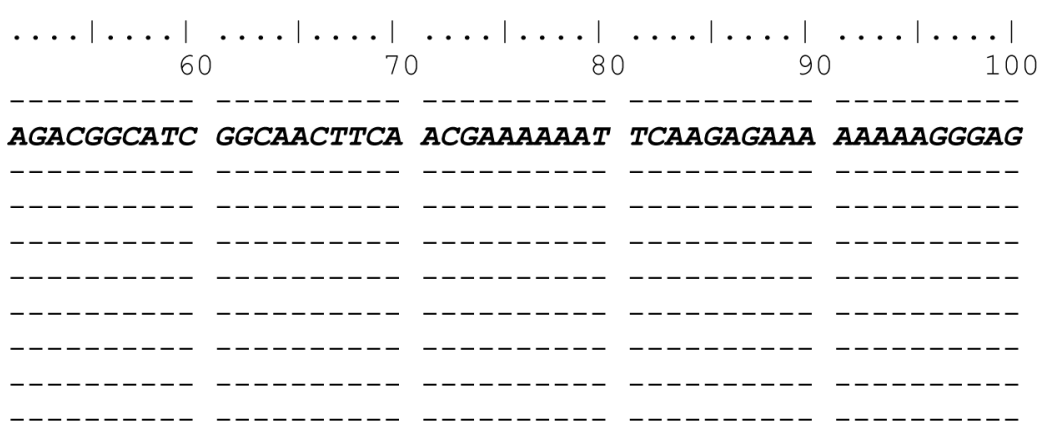

$\begin{array}{llll}1181 & \text { NORMAL } & (473 & \mathrm{bp}) \\ 1181 & \text { NORMAL } & (576 & \mathrm{bp}) \\ 1181 & \text { TLS } & (473 & \mathrm{bp}) \\ 5074 \mathrm{C} & \text { NORMAL } & (472 & \mathrm{bp}) \\ 5074 \mathrm{C} & \text { TLS } & (472 & \mathrm{bp}) \\ 5074 \mathrm{C} & \text { TLS } & (512 & \mathrm{bp}) \\ 4807 & \text { NORMAL } & (472 & \mathrm{bp}) \\ 4807 & \text { NORMAL } & (512 & \mathrm{bp}) \\ 4807 & \text { TLS } & (472 & \mathrm{bp}) \\ 4807 & \text { TLS } & (512 & \mathrm{bp})\end{array}$

$\ldots|\ldots| \ldots|\ldots| \ldots|\ldots| \ldots|\ldots| \ldots|\ldots| \ldots|\ldots| \ldots \mid$ 110 120

130

140

AACTTGATGC CCGCCGTGGC TGGCTATGGA GGAGGAAGGA AAAATTT-TA

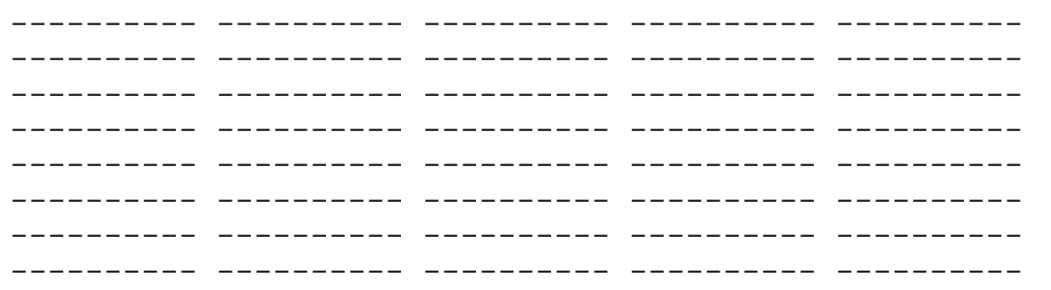


1181 NORMAL (473 bp) 1181 NORMAL (576 bp) 1181 TLS (473 bp) $5074 \mathrm{c}$ NORMAL (472 bp) $5074 \mathrm{c}$ TLS (472 bp) $5074 \mathrm{c}$ TLS (512 bp) 4807 NORMAL (472 bp) 4807 NORMAL (512 bp) 4807 TLS (472 bp) 4807 TLS (512 bp) $\ldots|\ldots| \ldots|\ldots| \ldots|\ldots| \ldots|\ldots| \ldots|\ldots| \ldots|\ldots|$

$$
160
$$$$
170
$$$$
180
$$$$
190
$$

CAAAGAGGGC ATCGGCAACT TCAACGGAAA AATTCGAGAG AAAAAAGAGG CAAAGAgGgC ATCGGCAACT TCAACGAAAA AATTCAAGAg AAAAAAGAgG CAAAGAGGgC ATCGGCAACT TCAACGGAAA AATTCGAGAg AAAAAAGAgG CAAAGAGGGC ATCGGCAACT TCAACGGAAA AATTCGAGA AAAAAAGAGG CAAAGAGGGC ATCGGCAACT TCAACGGAAA AATTCGAGAG AAAAAAGAGG CAAAGAGGGC ATCGGCAACT TCAACGGAAA AATTCGAGAG AAAAAAGAGG CAAAGAGGGC ATCGGCAACT TCAACGGAAA AATTCGAGAG AAAAAAGAGG CAAAGAGGGC ATCGGCAACT TCAACGGAAA AATTCGAGA AAAAAAGAgG CAAAGAGGgC ATCGGCAACT TCAACGgAAA AATTCGAgAg AAAAAAGAgG CAAAGAGGGC ATCGGCAACT TCAACGGAAA AATTCGAGAG AAAAAAGAGG
1181 NORMAL (473 bp) 1181 NORMAL (576 bp) 1181 TLS (473 bp) $5074 \mathrm{c}$ NORMAL (472 bp) $5074 \mathrm{c}$ TLS (472 bp) $5074 \mathrm{C}$ TLS (512 bp) 4807 NORMAL (472 bp) 4807 NORMAL (512 bp) 4807 TLS (472 bp) 4807 TLS (512 bp) $\cdots|\ldots|_{210} \ldots|\cdots|_{220} \ldots|\cdots|_{230} \ldots|\cdots|_{240} \ldots|\cdots|_{25}$

GAGAACTTGA TGCCCGCCGT GGCTGGCTAT GGAGGAGGAA GGAAAAATTT GAGAACTTGA TGCCCGCCGT GGCTGACTAT GGAGGAGGAA GGAAAAATTT GAGAACTTGA TGCCCGCCGT GGCTGGCTAT GGAGGAGGAA GGAAAAATTT GAGAACTTGA TGCCCGCCGT GGCTGGCTAT GGAGGAGGAA GGAAAAATTT GAGAACTTGA TGCCCGCCGT GGCTGGCTAT GGAGGAGGAA GGAAAAATTT GAGAACTTGA TGCCCGCCGT GGCTGGCTAT GGAGGAGGAA GGAAAAATTT GAGAACTTGA TGCCCGCCGT GGCTGGCTAT GGAGGAGGAA GGAAAAATTT GAGAACTTGA TGCCCGCCGT GGCTGGCTAT GGAGGAGGAA GGAAAAATTT GAGAACTTGA TGCCCGCCGT GGCTGGCTAT GGAGGAGGAA GGAAAAATTT GAGAACTTGA TGCCCGCCGT GGCTGGCTAT GGAGGAGGAA GGAAAAATTT
1181 NORMAL (473 bp) 1181 NORMAL (576 bp) 1181 TLS (473 bp) 5074c NORMAL (472 bp) $5074 \mathrm{C}$ TLS (472 bp) $5074 \mathrm{C}$ TLS (512 bp) 4807 NORMAL (472 bp) 4807 NORMAL (512 bp) 4807 TLS (472 bp) 4807 TLS (512 bp)

$$
\left.\left.\left.\left.\left.\ldots|\ldots|\right|_{260} \ldots|\ldots|\right|_{270} \ldots|\ldots|\right|_{280} \ldots|\ldots|\right|_{290} \ldots|\ldots|\right|_{30}
$$

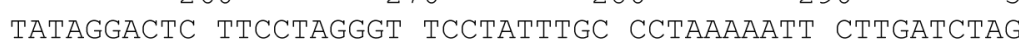
TATAAGACTC TTCCCAGGGT TTCTATTTGC CCTAGAAATC CTTGATCTAG TATAGGACTC TTCCTAGGGT TCCTATTTGC CCTAAAAATT CTTGATCTAG TATAGGACTC TTCCTAGGGT TCCTATTTGC CCTAAAAATT CTTGATCTAG TATAGGACTC TTCCTAGGGT TCCTATTTGC CCTAAAAATT CTTGATCTAG TATAGGACTC TTCCTAGGGT TCCTATTTGC CCTAAAAATT CTTGATCTAG TATAGGACTC TTCCTAGGGT TCCTATTTGC CCTAAAAATT CTTGATCTAG TATAGGACTC TTCCTAGGGT TCCTATTTGC CCTAAAAATT CTTGATCTAG TATAGGACTC TTCCTAGGGT TCCTATTTGC CCTAAAAATT CTTGATCTAG TATAGGACTC TTCCTAGGGT TCCTATTTGC CCTAAAAATT CTTGATCTAG
1181 NORMAL (473 bp) 1181 NORMAL (576 bp) 1181 TLS (473 bp) 5074c NORMAL (472 bp) $5074 \mathrm{C}$ TLS (472 bp) $5074 \mathrm{C}$ TLS (512 bp) 4807 NORMAL (472 bp) 4807 NORMAL (512 bp) 4807 TLS $(472 \mathrm{bp})$ 4807 TLS (512 bp) $\cdots|\cdots|_{310} \ldots|\cdots|_{320} \ldots|\cdots|_{330} \ldots|\cdots|_{340} \ldots|\cdots|_{350}$

TCGGATACGG AGAGGAGGAA GAAGAAGACT CTCGA----- ---.----TCGGATACGG AGAGGAGGAA GAAGAAGACT CTCGA----- --------TCGGATACGG AGAGGAGGAA GAAGAAGACT CTCGA----- --------TCGGATACGG AGAGGAGGAA GAAGAAGACT CTCGA----- -------TCGGATACGG AGAGGAGGAA GAAGAAGACT CTCGA----- --------TCGGATACGG AGAGGAGGAA GAAGAAGACT CTCGATCTAG TCGGATACGG TCGGATACGG AGAGGAGGAA GAAGAAGACT CTCGA----- --------TCGGATACGG AGAGGAGGAA GAAGAAGACT CTCGATCTAG TCGGATACGG TCGGATACGG AGAGGAGGAA GAAGAAGACT CTCGA-

TCGGATACGG AGAGGAGGAA GAAGAAGACT CTCGATCtAg tCGGATACGg $\ldots|\ldots| \ldots|\ldots| \ldots|\ldots| \ldots|\ldots| \ldots|\ldots| \ldots|\ldots| \ldots \mid$

1181 NORMAL (473 bp) 1181 NORMAL (576 bp) 1181 TLS (473 bp) $5074 \mathrm{c}$ NORMAL $(472 \mathrm{bp})$ $5074 \mathrm{c}$ TLS (472 bp) $5074 \mathrm{c}$ TLS (512 bp) 4807 NORMAL (472 bp) 4807 NORMAL (512 bp) 4807 TLS (472 bp)

\begin{tabular}{|c|c|c|c|c|}
\hline & & & & \\
\hline & -- & GTCTT & TCT & \\
\hline & -- & --GTCTT & ГТСТ & \\
\hline- & -- & --GTCTT & ITCT & \\
\hline & -- & -GTCTT & TGTT & \\
\hline & --- & $-----\mathrm{GTCTT}$ & TCT & \\
\hline$A A$ & $G A C T$ & CTCGAGTCTT & TCT & \\
\hline-- & --- & -GTCTT & $\mathrm{CT}$ & \\
\hline ;GAA & GAAGAAGACT & CTC & & \\
\hline & --- & --- & & \\
\hline & $G$ & & & \\
\hline
\end{tabular}
4807 TLS (512 bp) 
1181 NORMAL (473 bp) 1181 NORMAL (576 bp) 1181 TLS (473 bP) $5074 \mathrm{c}$ NORMAL (472 bp) $5074 \mathrm{c}$ TLS (472 bp) $5074 \mathrm{C}$ TLS (512 bP) 4807 NORMAL (472 bp) 4807 NORMAL (512 bP) 4807 TLS (472 bp) 4807 TLS (512 bP) $\ldots|\cdots|_{410} \ldots|\cdots|_{420} \ldots|\cdots|_{430} \ldots|\cdots|_{440} \ldots|\cdots|_{450}$

-TAACCATGA GCTTGATGGg CCAAAATCGA GTGGGCTTGA TTTTTAGAAC TTAACCATGA GCTTGATGGG CCAAAATCGA GTGGGCTTGA TTTTTAGAAC -TAACCATGA GCTTGATGGg CCAAAATCGA GTGGGCTTGA TTTTTAgAAC -TAACCATGA GCTTGATGGG CCAAAATCGA GTGGGCTTGA TTTTTAgAAC -TAACCATGA GCTTGATGGG CCAAAATCGA GTGGGCTTGA TTTTTAGAAC -TAACCATGA GCTTGATGgG CCAAAATCGA GTGGGCTTGA TTTTTAgAAC -TAACCATGA GCTTGATGGG CCAAAATCGA GTGGGCTTGA TTTTTAGAAC -TAACCATGA GCTTGATGGg CCAAAATCGA GTGGGCTTGA TTTTTAGAAC -TAACCATGA GCTTGATGGg CCAAAATCGA GTGGGCTTGA TTTTTAGAAC -TAACCATGA GCTTGATGgG CCAAAATCGA GTGGgCTTGA TTTTTAgAAC

$\begin{array}{lll}1181 & \text { NORMAL } & (473 \mathrm{bp}) \\ 1181 & \text { NORMAL } & (576 \mathrm{bp}) \\ 1181 & \text { TLS } & (473 \mathrm{bp}) \\ 5074 \mathrm{C} & \text { NORMAL } & (472 \mathrm{bp}) \\ 5074 \mathrm{C} & \text { TLS } & (472 \mathrm{bp}) \\ 5074 \mathrm{C} & \text { TLS } & (512 \mathrm{bp}) \\ 4807 & \text { NORMAL } & (472 \mathrm{bp}) \\ 4807 & \text { NORMAL } & (512 \mathrm{bp}) \\ 4807 & \text { TLS } & (472 \mathrm{bp}) \\ 4807 & \text { TLS } & (512 \mathrm{bp})\end{array}$

$\cdots|\cdots|_{460} \ldots|\cdots|_{470} \ldots|\cdots|_{480} \ldots|\cdots|_{490} \ldots|\cdots|_{500}$

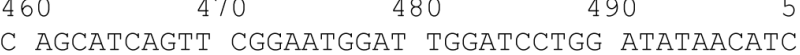


AgGGTATTAC AgCATCAgtT CGgAatgGat TGgAtCCTGg ATATAACATC AgGGTATTAC AGCATCAGTT CGGAATGGAT TGGATCCTGG ATATAACATC AGGGTATTAC AgCATCAGTT CGGAATGGAT TGgATCCTGG ATATAACATC AGGGTATTAC AGCATCAGTT CGGAATGGAT TGGATCCTGG ATATAACATC AGGGTATTAC AGCATCAGTT CGGAATGGAT TGGATCCTGG ATATAACATC

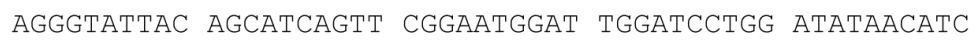
AGGGTATTAC AGCATCAGTT CGGAATGGAT TGGATCCTGG ATATAACATC AgGgtattac AgCAtCAgtT CGgAatgGAT tgGatCCtgg AtAtAACAtC
1181 NORMAL (473 bp) 1181 NORMAL (576 bP) 1181 TLS 5074 c NORMAI (472 bP) $5074 \mathrm{c}$ TLS (472 bp) $5074 \mathrm{c}$ TLS (512 bp) 4807 NORMAL (472 bp) 4807 NORMAL (512 bp) 4807 TLS (472 bp) 4807 TLS (512 bp)

$$
\cdots|\cdots|_{510} \ldots|\cdots|_{520} \ldots|\cdots|_{530} \ldots|\cdots|_{540} \ldots|\cdots|_{55}
$$

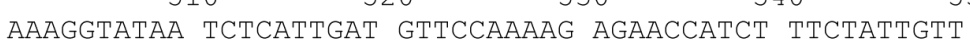
AAAGGTATAA TCTCATTGAT GTTCCAAAAG AGAACCATCT TTCTATTGTT AAAGGTATAA TCTCATTGAT GTTCCAAAAG AGAACCATCT TTCTATTGTT AAAGGTATAA TCTCATTGAT GTTCCAAAAG AGAACCATCT TTCTATTGTT AAAgGTATAA TCTCATTGAT GTTCCAAAAG AGAACCATCT TTCTATTGTT AAAGGTATAA TCTCATTGAT GTTCCAAAAG AGAACCATCT TTCTATTGTT AAAGGTATAA TCTCATTGAT GTTCCAAAAG AGAACCATCT TTCTATTGTT AAAGGTATAA TCTCATTGAT GTTCCAAAAG AGAACCATCT TTCTATTGTT AAAGGTATAA TCTCATTGAT GTTCCAAAAG AGAACCATCT TTCTATTGTT AAAgGTATAA TCTCATTGAT GTTCCAAAAg AgAACCATCT TTCTATTGTT $\begin{array}{lll}1181 & \text { NORMAL } & (473 \mathrm{bp}) \\ 1181 & \text { NORMAL } & (576 \mathrm{bp}) \\ 1181 & \text { TLS } & (473 \mathrm{bp}) \\ 5074 \mathrm{C} & \text { NORMAL } & (472 \mathrm{bp}) \\ 5074 \mathrm{C} & \text { TLS } & (472 \mathrm{bp}) \\ 5074 \mathrm{C} & \text { TLS } & (512 \mathrm{bp}) \\ 4807 & \text { NORMAL } & (472 \mathrm{bp}) \\ 4807 & \text { NORMAL } & (512 \mathrm{bp}) \\ 4807 & \text { TLS } & (472 \mathrm{bp}) \\ 4807 & \text { TLS } & (512 \mathrm{bp})\end{array}$ $\ldots|\ldots| \ldots|\ldots| \ldots|\ldots| \ldots|\ldots| \ldots|\ldots|$ 560 570 580 TATCCTGATA AAGTGCTGGG ATATCTGTGC TGGTAAAATC AGTCAGAGCC TATCCTGATA AAGTGCTGGg ATATCTGTGC TGgTAAAATC AGTCAGAGCC TATCCTGATA AAgTGCTGGg ATATCTGTGC TGgtAAAATC AGTCAGAGCC

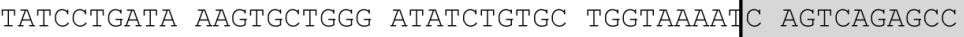


TATCCTGATA AAgTGCTGg ATATCTGTGC TGgTAAAAT A AgTCAgAgCC TATCCTGATA AAGTGCTGGG ATATCTGTGC TGGTAAAATC AgTCAGAGCC TATCCTGATA AAgTGCTGgG ATATCTGTGC TGgTAAAATC AgTCAGAGCC TATCCTGATA AAGTGCTGGg ATATCTGTGC TGGTAAAAT AGTCAGAGCC

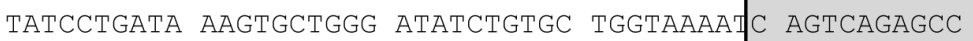

\begin{tabular}{|c|c|c|c|}
\hline & & & $\cdots|\cdots|_{610} \ldots \mid$ \\
\hline 1181 & NORMAL & (473 bp) & AAAGGTGGGG AAAGAG \\
\hline L81 & NORMAL & (576 bp) & AAAGGTGGGG AAAGAG \\
\hline 1181 & TLS & (473 bp) & AAAGGTGGGG AAAGAG \\
\hline $5074 c$ & NORMAL & (472 bp) & AAAGGTGGGG AAAGAG \\
\hline $5074 c$ & TLS & $(472 \mathrm{bp})$ & AAAGGTGGGG AAAGAG \\
\hline $5074 c$ & TLS & (512 bp) & AAAGGTGGGG AAAGAG \\
\hline 4807 & NORMAL & (472 bp) & AAAGGTGGGG AAAGAG \\
\hline 4807 & NORMAL & (512 bp) & AAAGGTGGGG AAAGAG \\
\hline 4807 & TLS & $(472 \mathrm{bp})$ & AAAGGTGGGG AAAGAG \\
\hline 4807 & TLS & $(512 \mathrm{bp})$ & AAAGGTGGGG AAAGAA \\
\hline
\end{tabular}

Figure 5. The comparison of nucleotide sequences of the polymerase chain reaction (PCR) products amplified using the F4(10)-1181BglII primer set. Genomic DNA from clones 1181 [normal and Truncated Leaf Syndrome (TLS)], 5074c (normal and TLS) and 4807 [normal and were used as template. Presence of extra region is bolded and italicised, while primer sequences are boxed and shaded. 


\section{CONCLUSION}

The subtractive hybridisation method (G-RDA) was used in this study to reveal the genomic differences present in normal and TLS oil palm ramet. A few different products were successfully cloned and characterised. The obtained data suggests that the differences between the normal and TLS genome are due to single nucleotide substitution and an insertion or a deletion of a portion of sequences in the normal and TLS genomes. Further verification using the oil palm clones from the same variety is needed to elucidate the ability of the two sets of primer pair [F4(6)-1181BgIII and F4(10)-1181BgIII] as a candidate biomarker to identify TLS plantlets during tissue culture process.

\section{ACKNOWLEDGEMENT}

The authors thank Felda Agricultural Services Sdn Bhd for kindly providing oil palm samples, Ministry of Higher Education, Malaysia for funding this project (FRGS/FASA/1-10/ST/UPM/03/08), Universiti Putra Malaysia for providing the first author the Graduate Research Fellowship (GRF) and Malaysian Palm Oil Board (MPOB) for providing oil palm genomic.

\section{REFERENCES}

ABDULLAH, R; ZAINAL, A; YEW HENG, W; CHUI LI, L; CHEE BENG, Y; MEI PHING, L; ABDULLAH SIRAJUDDIN, S; SOO PING, W Y; LOURDES JOSEPH, J and AZMA JUSOH, S (2005). Immature embryo: A useful tool for oil palm (Elaeis guineensis Jacq.) genetic transformation studies. Electronic J. Biotechnology Vol. 8(1): 24-34.

BROWER, V (2011). Biomarkers: Portents of malignancy. Nature Vol. 471(7339): S19-S21.

CHEN, Z J; PHILLIPS, $\mathrm{R}$ L and RINES, H W (1998). Maize DNA enrichment by representational difference analysis in a maize chromosome addition line of oat. Theoretical and Applied Genetics Vol. 97(3): 337-344.

CHO, T J and PARK, S S (1998). A simulation of subtractive hybridization. Nucleic Acids Research Vol. 26(6): 1440-1448.

CORLEY, R H and TINKER, P B (2003). The Oil Palm. Fourth edition. Oxford: Blackwell Science Ltd. p. 201-215.

CORLEY, R H V; LEE, C H; LAW, I M and WONG, C $Y$ (1986). Abnormal flower development in oil palm clones. The Planter Vol. 62(723): 233-240.
CULLIS, C A and KUNERT, K J (2000). Isolation of tissue culture-induced polymorphism in bananas by representational difference analysis. Acta Horticulture Vol. 530: 421-428.

CULLIS, C A C and ABDULLAH, M A M O (2007). Development of markers for the mantled phenotype (and somaclonal variants in general) in oil palm. Paper presented at the PIPOC 2007 International Palm Oil Congress - Empowering Change. 26-30 August 2007, Kuala Lumpur, Malaysia.

D'AMATO, F (1977). Cytogenetics of differentiation in tissue and cell culture. Applied and Fundamental Aspects of Plant Cell, Tissue and Organ Culture. p. 343464.

DELLAPORTA, S L; WOOD, J and HICKS, J B (1983). A plant DNA minipreparation: Version II. Plant Molecular Biology Reporter Vol. 1(4): 19-21.

HABIB, S H; SYED-ALWEE, S S R; HO, C L; ONG-ABDULLAH, M; SINNIAH, U $\mathrm{R}$ and NAMASIVAYAM, P (2012a). Morpho-histological characterization of truncated leaf syndrome seedlings: An oil palm (E. guineensis Jacq.) somaclonal variant. Acta Physiologiae Plantarum Vol. 34(1): 17-28.

HABIB, SH; OOI, SE; NOVÁK, O; TARKOWSKÁ, D; ROLČÍK, J; DOLEŽAL, K; SYED-ALWEE, S S R; HO, C L and NAMASIVAYAM, P (2012b). Comparative mineral and hormonal analyses of wild type and TLS somaclonal variant derived from oil palm (Elaeis guineensis Jacq. var. tenera) tissue culture. Plant Growth Regulation Vol. 68(2): 313-317.

JONES, L H (1974). Propagation of clonal oil palms by tissue culture. Oil Palm News Vol. 17: 1-8.

LEVA, A R; PETRUCCELLI, R and RINALDI, L M R (2012). Somaclonal variation in tissue culture: a case study with olive. Recent Advances in Plant in vitro Culture.

LISITSYN, N; LISITSYN, N and WIGLER, M (1993). Cloning the differences between two complex genomes. Science Vol. 259: 946-950.

MATTHES, M; SINGH, R; CHEAH, S C and KARP, A (2001). Variation in oil palm (Elaeis guineensis Jacq.) tissue culture-derived regenerants revealed by AFLPs with methylation-sensitive enzymes. Theoretical and Applied Genetics Vol. 102(6-7): 971-979.

MILNER, J J; CECCHINI, E and DOMINY, P J (1995). A kinetic model for subtractive hybridization. Nucleic Acids Research Vol. 23(1): 176-187. 
MPOB (2014). Economics \& Industry Development Division. MPOB, Bangi.

OH, TJ; CULLIS, MA;KUNERT, K; ENGELBORGHS, I; SWENNEN, R and CULLIS, C A (2007). Genomic changes associated with somaclonal variation in banana (Musa spp.). Physiologia Plantarum Vol. 129(4): 766-774.

PANAUD, O; VITTE, C; HIVERT, J; MUZLAK, S; TALAG, J; BRAR, D and SARR, A (2002). Characterization of transposable elements in the genome of rice (Oryza sativa L.) using representational difference analysis (RDA). Molecular Genetics and Genomics Vol. 268(1): 113-121.

PHILLIPS, R L; KAEPPLER, S M and OLHOFT, P (1994). Genetic instability of plant tissue cultures: Breakdown of normal controls. Proc. of the National Academy of Sciences Vol. 91(12): 5222-5226.

PLUHAR, S A; ERICKSON, L and PAULS, K P (2001). Effects of tissue culture on a highly repetitive DNA sequence (E180 satellite) in Medicago sativa. Plant Cell, Tissue and Organ Culture Vol. 67(2): 195199.

SINGH, R; ONG-ABDULLAH, M; LOW, E T L; MANAF, M A A; ROSLI, R; NOOKIAH, R; OOI, L C L; OOI, S E; CHAN, K L; HALIM, $M$ A and AZIZI, N (2013). Oil palm genome sequence reveals divergence of interfertile species in Old and New worlds. Nature Vol. 500(7462): 335-339.

SOGEKE, A K (1998). Stages in the vegetative propagation of oil palm, Elaeis guineensis Jacq. through tissue culture. J. Oil Palm Res. Vol. 10(2): 1-9.

SOH, A C; WONG, G; TAN, C C; CHEW, P S; HOR, T Y; CHONG, S P and GOPAL, K (2001). Recent advances towards commercial production of elite oil palm clones. Proc. of the PIPOC 2001 International Palm Oil Congress - Agriculture Conference: p. 33-44.

SWARTZ, H J (1991). Post culture behaviour, genetic and epigenetic effects and related problems.
Micropropagation: Technology and Application. Springer, Netherlands. p. 95-122

TAN, C C; WONG, G and SOHL, A C (1999). Acclimatization and handling of oil palm tissue cultured plantlets for large scale commercial production. Proc. of the 1999 PORIM International Palm Oil Congress. p. 1-6.

VOSTER, B; KUNERT, K and CULLIS, C (2002). Use of representational difference analysis for the characterization of sequence differences between date palm varieties. Plant Cell Reports Vol. 21(3): 271275 .

VOS, P; HOGERS, R; BLEEKER, M; REIJANS, M; LEE, T V D; HORNES, M; FRITERS, A; POT, J; PALEMAN, J; KUIPER, M and ZABEAU, M (1995). AFLP: a new technique for DNA fingerprinting. Nucleic Acids Research Vol. 23(21): 4407-4414.

WELSH, J and MCCLELLAND, M (1990). Fingerprinting genomes using PCR with arbitrary primers. Nucleic Acids Research Vol. 18(24): 72137218 .

WILLIAMS, J G; KUBELIK, A R; LIVAK, K J; RAFALSKI, J A and TINGEY, S V (1990). DNA polymorphisms amplified by arbitrary primers are useful as genetic markers. Nucleic Acids Research Vol. 18(22): 6531-6535.

ZIOGAS, D (2011). Standard and research for ovarian cancer: Emphasis on interactome-based tests for screening or treatment including HIPEC. Gastric and Breast Cancer Vol. 10(3): 146-150.

ZOLDOS, V; SILJAK-YAKOVLEV, S; PAPES, D; SARR, A and PANAUD, O (2001). Representational difference analysis reveals genomic differences between $Q$. robur and $Q$. suber: Implications for the study of genome evolution in the genus Quercus. Molecular Genetics and Genomics Vol. 265(2): 234-241. 